In cooperation with the U.S. Department of Agriculture, Natural Resources Conservation Service; San Patricio Soil and Water Conservation District; and The Welder Wildlife Foundation

\title{
Hydrologic Conditions and Quality of Rainfall and Storm Runoff in Agricultural and Rangeland Areas in San Patricio County, Texas, 2000-2001
}

Open-File Report 02-291

U.S. Department of the Interior U.S. Geological Survey 
U.S. Department of the Interior

U.S. Geological Survey

\section{Hydrologic Conditions and Quality of Rainfall and Storm Runoff in Agricultural and Rangeland Areas in San Patricio County, Texas, 2000-2001}

By Darwin J. Ockerman

U.S. GEOLOGICAL SURVEY

Open-File Report 02-291

In cooperation with the U.S. Department of Agriculture, Natural Resources Conservation Service; San Patricio Soil and Water Conservation District; and The Welder Wildlife Foundation

Austin, Texas

2002 


\section{U.S. DEPARTMENT OF THE INTERIOR}

Gale A. Norton, Secretary

\section{U.S. GEOLOGICAL SURVEY}

Charles G. Groat, Director

Any use of trade, product, or firm names is for descriptive purposes only and does not imply endorsement by the U.S. Government.

For additional information write to

\section{District Chief}

U.S. Geological Survey

8027 Exchange Dr.

Austin, TX 78754-4733

E-mail: dc_tx@usgs.gov

Copies of this report can be purchased from

U.S. Geological Survey

Information Services

Box 25286

Denver, CO 80225-0286

E-mail: infoservices@usgs.gov 


\section{CONTENTS}

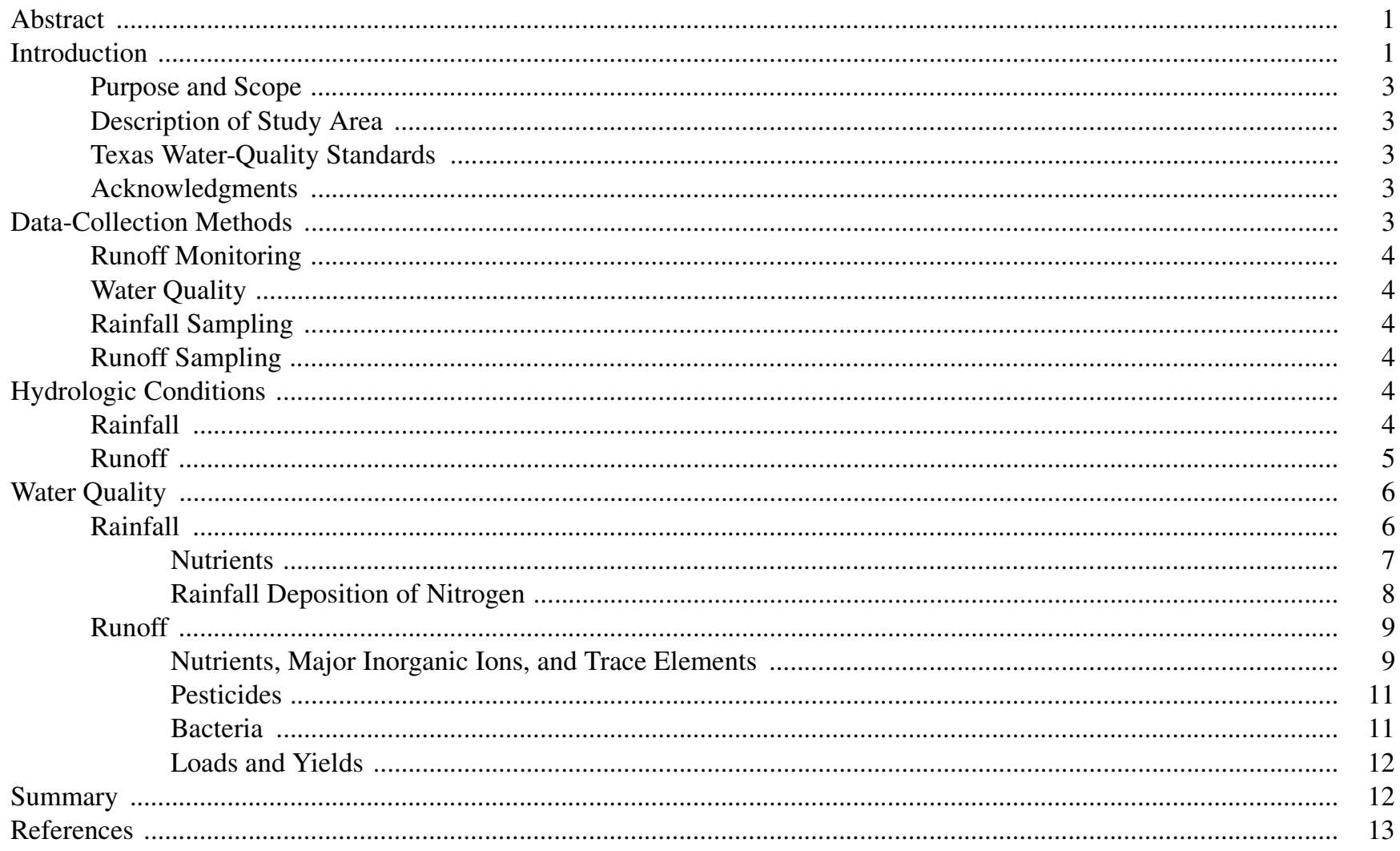

\section{PLATE}

[Plate is in pocket]

1. Map showing aerial photograph of agricultural and rangeland watersheds

\section{FIGURES}

1. Map showing Coastal Bend area of South Texas and study area

2. Hydrograph showing rainfall, discharge, and subsample-collection timing at watershed site 2 during storm event, August 30, 2001

3-5. Graphs showing:

3. Mean monthly rainfall at National Oceanic and Atmospheric Administration (NOAA) weather station, 1965-2001, and monthly study area rainfall, 2000-2001

4. Comparison of computed and estimated (from regression) total nitrogen deposition for sampled rainfall events, June 2000-August 2001

5. Comparison of runoff concentrations for selected constituents between mixed agricultural watershed (Moody Creek watershed) and rangeland watersheds (watersheds 1 and 2), 2000-2001

\section{TABLES}

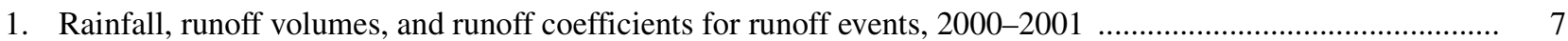

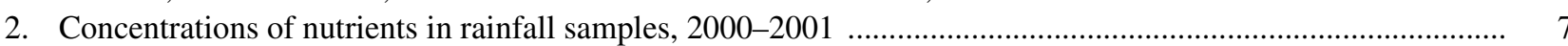


3. Summary statistics of selected nutrient concentrations in rainfall samples, 2000-2001

4. Event-mean concentrations for selected properties and constituents in runoff samples, 2000-2001 ................. 15

5. Summary statistics of event-mean concentrations for selected constituents in runoff samples, 2000-2001 ....... 18

6. Densities of bacteria in runoff samples, 2000-2001

7. Summary statistics of bacteria densities in combined runoff samples, 2000-2001

8. Monthly and annual loads of selected constituents in runoff, 2000-2001 


\title{
Hydrologic Conditions and Quality of Rainfall and Storm Runoff in Agricultural and Rangeland Areas in San Patricio County, Texas, 2000-2001
}

\author{
By Darwin J. Ockerman
}

\section{Abstract}

During 2000-2001, rainfall and runoff were monitored in one mixed agricultural watershed and two rangeland watersheds in San Patricio County, located in the Coastal Bend area of South Texas. During this period, five rainfall samples were collected and analyzed for selected nutrients. Ten runoff samples from nine runoff events were collected at the three watershed monitoring stations. Runoff samples were analyzed for selected nutrients, major ions, trace elements, pesticides, and bacteria.

Study area rainfall during 2000 and 2001 was 33.27 and 28.20 inches, respectively, less than the long-term average annual of 36.31 inches. Total runoff from the study area watersheds during 2000-2001 was 2.46 inches; the regional average is about 2 inches per year. Rainfall and runoff during the study period was typical of historical patterns, with periods of below average rainfall interspersed with extreme events. Three individual storm events accounted for about 29 percent of the total rainfall and 86 percent of the total runoff during 20002001.

Runoff concentrations of nutrients, major ions, and trace elements generally were larger in the mixed agricultural watershed than runoff concentrations in the rangeland watersheds. Pesticides were detected in two of eight runoff samples. Three pesticides (atrazine, deethylatrazine, and trifluralin) were detected in very small concentrations; only deethylatrazine was detected in a concentration greater than the laboratory minimum reporting level.

Bacteria in agricultural and rangeland runoff is a potential water-quality concern as all fecal coliform and E. coli densities in the runoff samples exceeded Texas Surface Water Quality Standards for receiving waters. However, runoff and relatively large bacteria densities represent very brief and infrequent conditions, and the effect on downstream water is not known.

Rainfall deposition is a major source of nitrogen delivered to the study area. Rainfall nitrogen (mostly ammonia and nitrate) exceeded the runoff yield. The average annual rainfall deposition of total nitrogen on the study area watersheds was 1.3 pounds per acre. In contrast, an average annual yield of 0.57 and 0.21 pound per acre of total nitrogen in runoff exited the mixed agricultural watershed and the rangeland watersheds, respectively.

\section{INTRODUCTION}

The Coastal Bend bays and estuaries system of Texas is one of 28 estuaries in the United States that have been designated as "Estuaries of National Significance" (Texas Natural Resource Conservation Commission, 1996). The Coastal Bend bays and estuaries are affected by nonpoint-source runoff from agricultural land uses within the 12-county Coastal Bend area of South Texas (fig. 1). Agricultural land uses are predominant on about 88 percent of the Coastal Bend area and range from cattle grazing to row crop farming. About two-thirds of this agricultural land use is rangeland (Quenzer and others, 1998), the largest single land use category in the Coastal Bend area.

Because information on the characteristics of runoff from rangeland in the Coastal Bend area is meager, the U.S. Geological Survey (USGS) studied the hydrology and water quality of three watersheds consisting of 14,264 acres of mixed agricultural land and coastal plains rangeland in San Patricio County during January 2000-December 2001. The study was done in cooperation with the U.S. Department of Agriculture, Natural Resources Conservation Service; San Patricio Soil and Water Conservation District; and The Welder Wildlife Foundation. 


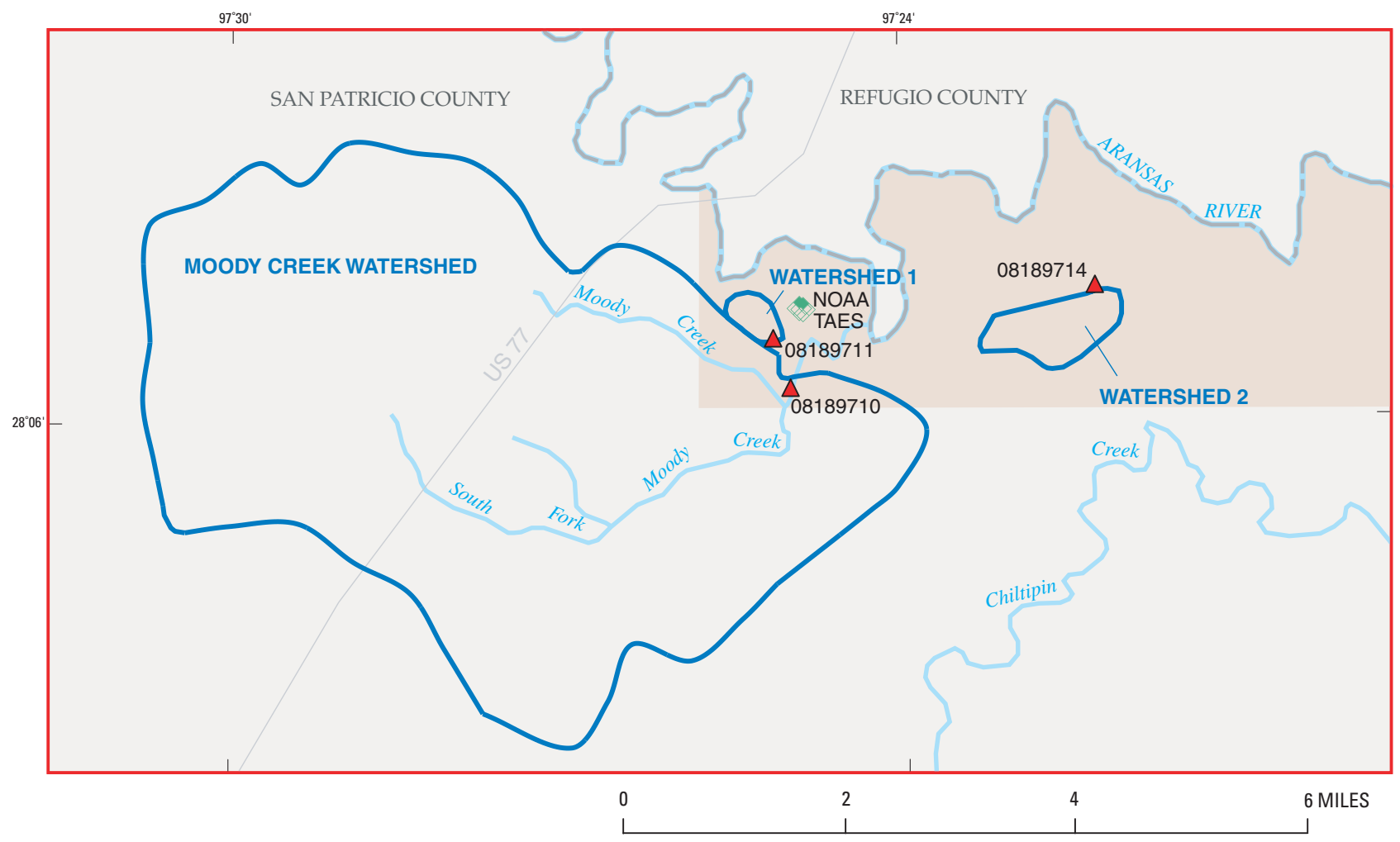

EXPLANATION

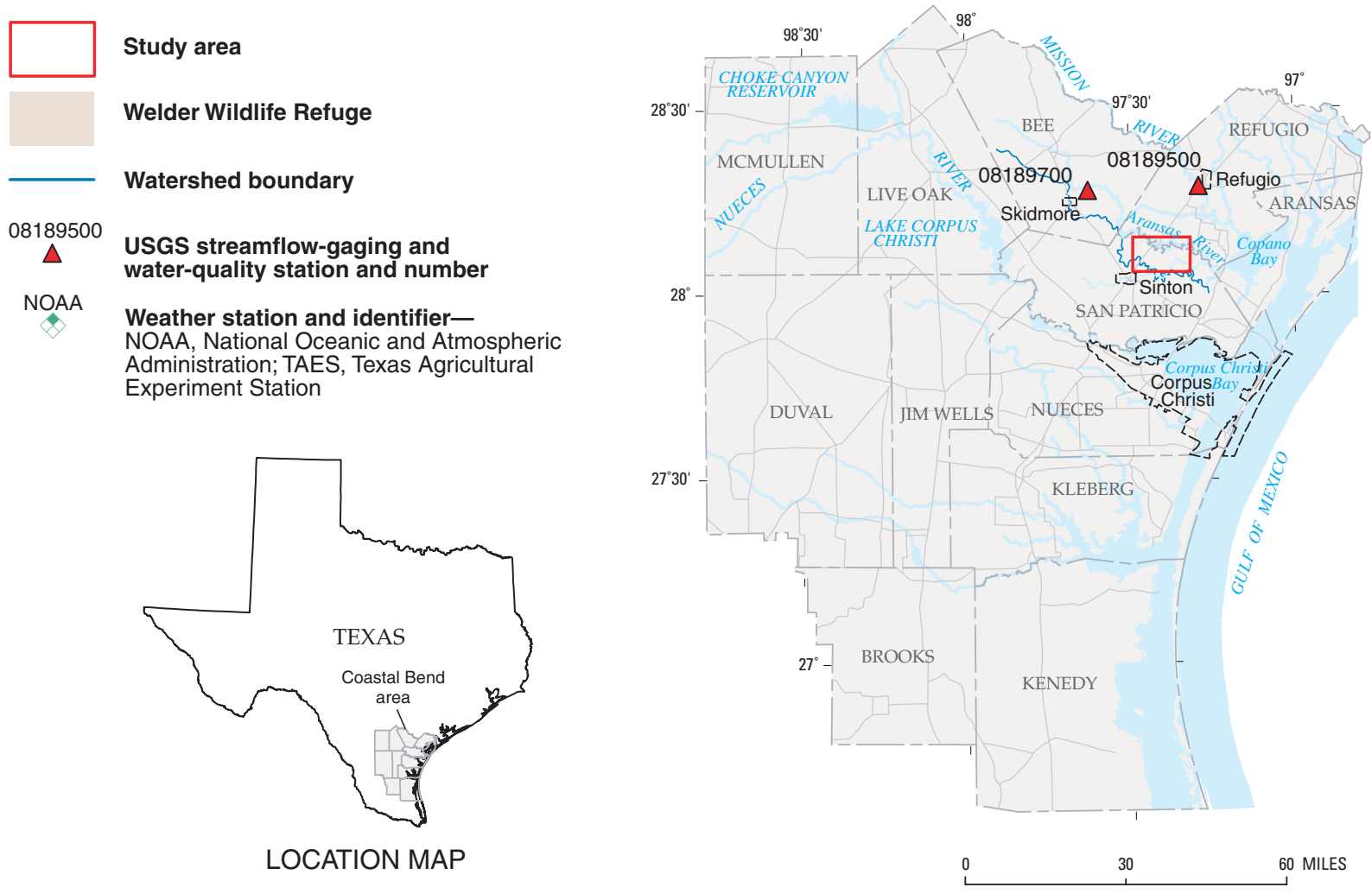

Figure 1. Coastal Bend area of South Texas and study area. 


\section{Purpose and Scope}

This report presents the results of a study to describe hydrologic conditions, to characterize the quality of rainfall, and to characterize the quantity and quality of stormwater runoff in one mixed agricultural watershed and two rangeland watersheds in San Patricio County in the Coastal Bend area of South Texas. Rainfall samples were collected in the mixed agricultural watershed at a streamflow-gaging and water-quality station equipped with an automatic rainfall collector. Rainfall samples were analyzed for selected nutrients. Runoff samples were collected in each of the three watersheds at a streamflow-gaging and water-quality station equipped with automatic water samplers. Runoff samples were analyzed for selected nutrients, major inorganic ions, trace elements, and pesticides. Loads and yields of selected constituents entering the receiving bays and estuaries from these watersheds were estimated for 2000-2001.

\section{Description of Study Area}

The study area watersheds are delineated on the aerial photograph on plate 1 . The Moody Creek mixed agricultural watershed is the largest $(13,818$ acres). It is mostly rangeland, but also includes about 2,500 acres of cropland in the upper part of the watershed as well as U.S. highway right-of-way. Soils in the Moody Creek watershed are largely a mixture of sandy loams and clay loams (Soil Conservation Service, 1979). Watersheds 1 and 2 are entirely rangeland and located within the Welder Wildlife Refuge. Watershed 1 is about 97 acres of loamy sands. Watershed 2 is about 349 acres of clay soils. The topography of the area is relatively flat with altitudes ranging from about 25 feet above mean sea level near the outlets of the watersheds to about 75 feet above mean sea level in the upper Moody Creek watershed. Vegetation on the rangelands is a mixture of grass and varying densities of brush and woody vegetation (Drawe, 1997). The study area rangelands are used for grazing domestic livestock and to provide wildlife habitat.

Creeks in the study area are ephemeral, producing runoff only after heavy rains. The streamflow-gaging stations in watersheds 1 and 2 are located at the edge of fields (grassed ditches) that typically are dry. The lower reach of Moody Creek is inundated by backwater from the tidal reach of the Aransas River. All study area watersheds drain to the tidal segment of the Aransas River and then to Copano Bay (fig. 1).
The climate of the area is classified as subtropical (short, mild winters and long, hot and humid summers). Prevailing winds are from the southeast throughout the year (Baird and others, 1996).

\section{Texas Water-Quality Standards}

The Texas Natural Resource Conservation Commission (TNRCC) has designated water-quality standards and appropriate uses (such as aquatic life, contact or non-contact recreation, or drinking water) for specific stream, estuary, and bay segments (Texas Natural Resource Conservation Commission, 2002). To support the designated use of the water-body segments, standards for common water-quality indicators such as dissolved oxygen, temperature, $\mathrm{pH}$, dissolved minerals, and bacteria have been established for some stream and bay segments. The TNRCC has not developed segmentspecific standards for any of the creeks monitored during this study. However, some segment-specific standards have been established for the tidal segment of the Aransas River and Copano Bay, which receive runoff from the study area. The tidal segment of the Aransas River is designated for contact recreation and high aquatic life. Similarly, the Copano Bay segment is designated for contact recreation, high aquatic life, and oyster waters (State of Texas, 2000).

\section{Acknowledgments}

Special thanks are extended to Dr. D. Lynn Drawe, Director of The Welder Wildlife Foundation, for valuable project oversight and technical assistance and to Leroy Wolff, U.S. Department of Agriculture, Natural Resources Conservation Service, Sinton, Tex., for indispensable administrative and technical support.

\section{DATA-COLLECTION METHODS}

USGS streamflow-gaging and water-quality sampling stations were installed at the outlets of each of the study area watersheds (pl. 1; fig. 1) in May 2000 and operated through December 2001. The Texas Agricultural Experiment Station (TAES) in Corpus Christi has operated a weather station near watershed 1 since November 15, 2000. The wildlife refuge staff monitors a National Oceanic and Atmospheric Administration (NOAA) weather station (also near watershed 1) from which rainfall data have been collected since 1965 . 


\section{Runoff Monitoring}

Water-surface elevation (stage) was continuously recorded during runoff events at all three streamflowgaging stations using a gas-bubbler and pressure transducer system (Rantz and others, 1982). At Moody Creek (station 08189710), tidal backwater conditions result in a variable relation between stage and discharge. An acoustic doppler velocimeter also was used to measure stream velocity. Correlations between stage, velocity, and measured discharge were used to develop the discharge rating and to compute continuous discharge at this station (Patino and Ockerman, 1997). Relations between stage and runoff (discharge) were developed at watersheds 1 and 2 (stations 08189711 and 08189714, respectively) by making independent discharge measurements (Buchanan and Somers, 1969; Kennedy, 1984).

\section{Water Quality}

Water-quality samples were collected from two sources. Rainfall samples were collected primarily to determine rainfall nitrogen delivered to the study area. Runoff samples were collected to characterize runoff quality and to estimate constituent loads and yields transported to receiving waters.

\section{Rainfall Sampling}

Rainfall samples were collected at the Moody Creek station by an automatic rainfall collector. The collector is equipped with polyethylene buckets that are covered when rainfall is not occurring to prevent contamination and evaporation of the sample. A moisture sensor activates a mechanism to uncover the collection bucket when rainfall begins and to cover the sample when rainfall ends. About 0.2 inch of rain was required to provide sufficient sample volume for analysis. Rainfall samples were collected as single event-composite samples during rainfall events and therefore represent rainfall event-mean concentrations (EMCs). The samples were retrieved as soon as possible after a rainfall event, chilled, and shipped overnight to the USGS National Water Quality Laboratory (NWQL) in Denver, Colo., for analysis.

Rainfall samples were analyzed for the following forms of nitrogen: ammonia, dissolved organic, total organic, and nitrite plus nitrate. Total nitrogen concentrations were computed for each sample as the sum of ammonia, total organic, nitrite, and nitrate nitrogen. The samples also were analyzed for dissolved phosphorus, total phosphorus, and dissolved orthophosphate phosphorus. Field measurements of $\mathrm{pH}$, conductivity, and alkalinity also were made for selected samples.

\section{Runoff Sampling}

Automatic water samplers collected runoff samples during storm events. When streamflow-monitoring equipment detected runoff, automatic samplers were activated to collect discrete aliquots (subsamples). Aliquots were collected at a pre-programmed rate depending on the station. Aliquots were collected at 30-minute intervals at watersheds 1 and 2. Aliquots were collected hourly at the Moody Creek watershed, where runoff duration was longer. At the end of the runoff event, the aliquots from each station were combined into a single discharge-weighted composite sample (one sample from each station). The volume of each aliquot added to the composite sample was proportional to the stream discharge at the time of the aliquot collection. Thus, the analysis of the composite samples yielded EMCs that represent the discharge-weighted average concentrations during the runoff event. Figure 2 shows a rainfalldischarge hydrograph of a runoff event at watershed 2 on Aug. 30, 2001, and shows the timing of subsample collection.

After runoff samples were collected, they were chilled and bottled, necessary preservatives were added, and the samples were shipped overnight to the NWQL. Samples were analyzed for nutrients, major inorganic ions, trace elements, and dissolved pesticides.

In addition to the subsamples, discrete grab samples were collected. These samples were analyzed for bacteria at the USGS office in San Antonio, Tex.

\section{HYDROLOGIC CONDITIONS}

\section{Rainfall}

Annual rainfall statistics were computed from rainfall data measured at the NOAA weather station (pl. 1; fig. 1). The 37-year (1965-2001) average annual rainfall is 36.31 inches with a minimum of 15.49 inches in 1989 and a maximum of 59.46 inches in 1983. The standard deviation of annual rainfall, 10.09 inches, indicates relatively large differences in annual rainfall.

Study area rainfall (average of data from NOAA and TAES weather stations [pl. 1; fig. 1] during 2000 and 2001 was 33.27 and 28.20 inches, respectively. Monthly rainfall was below normal during 16 of the 


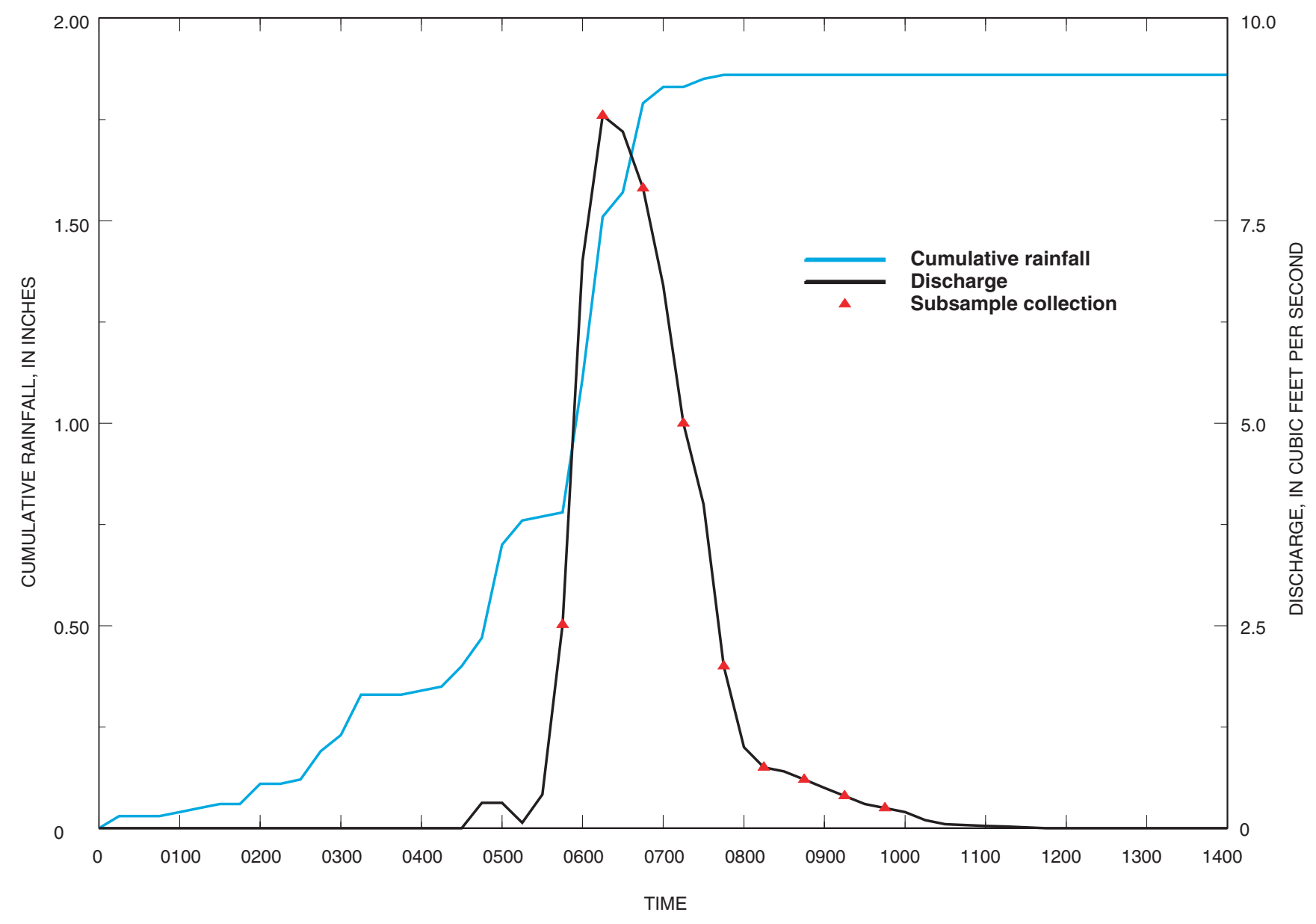

Figure 2. Hydrograph showing rainfall, discharge, and subsample-collection timing at watershed site 2 during storm event, August 30, 2001.

24 months. A few periods of heavy rainfall, interspersed between relatively dry periods, accounted for much of the annual rainfall. A comparison of 1965-2001 mean monthly rainfall at the NOAA station with monthly study area rainfall is shown in figure 3.

\section{Runoff}

Long-term USGS streamflow-gaging stations have been operated on the Aransas River near Skidmore (about 17.6 miles northwest of the study area) and on the Mission River at Refugio (about 15.6 miles northeast of the study area). The Aransas River station (08189700, fig. 1) has operated since 1964 and has a drainage area of 247 square miles. The Mission River station (08189500, fig. 1) has operated since 1939 and has a drainage area of 690 square miles. The rivers are unregulated and unaffected by diversions; both water- sheds are predominantly rangeland. The average annual runoff for the period of record at these two stations is 25,120 acre-feet (1.91 inches) for the Aransas River station and 87,200 acre-feet (2.37 inches) for the Mission River station. On the basis of these historical data, average annual runoff in the study area is about 2 inches, but like rainfall, can vary substantially from year to year.

Runoff in the study area during 2000-2001 corresponded to the rainfall pattern, with runoff events interspersed between long periods of no runoff. Nine runoff events (runoff at one or more of the stations) occurred. The dates of the runoff events, rainfall, runoff volume, and runoff coefficients (ratio of runoff volume, in inches, to rainfall volume, in inches) are listed in table 1. Most of the events were relatively small (in terms of runoff volume). There were three major runoff events. During Mar. 13-16, 2000, 6.11 inches of rain 


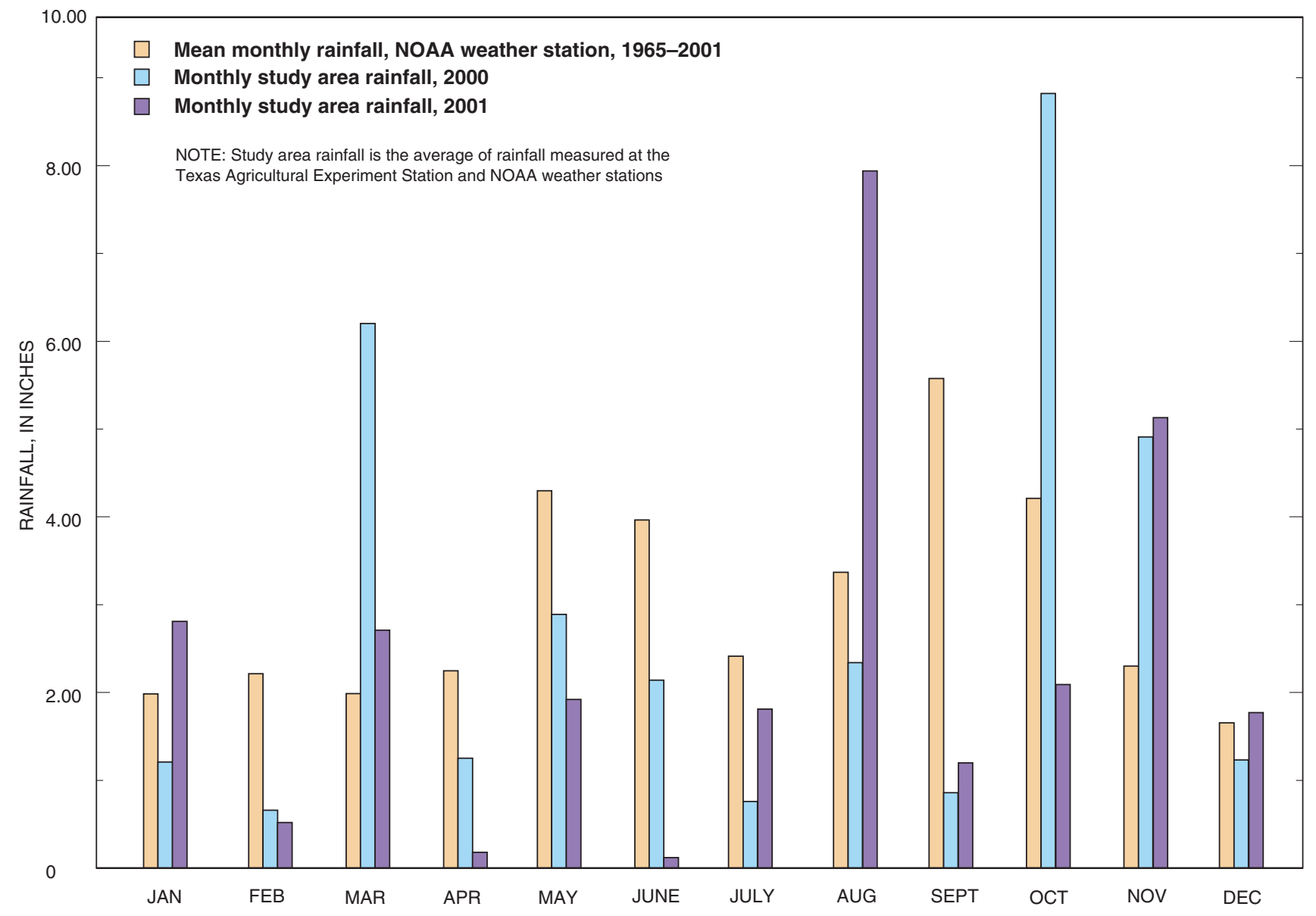

Figure 3. Mean monthly rainfall at National Oceanic and Atmospheric Administration (NOAA) weather station, 1965-2001, and monthly study area rainfall, 2000-2001.

produced 0.59 inch of runoff $^{1}$. During Aug. 28-Sept. 1, 2001, 7.46 inches of rain produced 1.08 inches of runoff. During Nov. 16-17, 2001, 4.17 inches of rain produced 0.34 inch of runoff. These three events produced 29 percent of the total rainfall and 86 percent of the total runoff for 2000-2001.

Generally, rain events of 2 inches or less resulted in little or no runoff depending on antecedent rainfall. The event of Oct. 6, 2000, produced 4.67 inches of rain after 6 months of very dry conditions. Runoff occurred at two of the three stations; total runoff was relatively small (less than $0.01 \mathrm{inch}$ ).

${ }^{1}$ Gaging equipment had not been installed when this event occurred. Runoff was estimated at 0.59 inch by regression of rainfall-runoff coefficients of subsequent measured events at each watershed.
During 2000-2001, 61.47 inches of rain on the study area produced 2.46 inches $(2,800$ acre-feet) of runoff. The runoff coefficient during this period was 0.038 . The runoff coefficients for the nine individual events that produced runoff ranged from 0.002 to 0.145 .

\section{WATER QUALITY}

\section{Rainfall}

Five rainfall samples collected at the Moody Creek station during June 2000-August 2001 represent 8.76 inches of rain. During the same period, 22.80 inches of rain fell on the study area; therefore, the samples represent about 38 percent of the study area rainfall during the 15-month period. 
Table 1. Rainfall, runoff volumes, and runoff coefficients for runoff events, 2000-2001

[Total study area runoff is sum of runoff from Moody Creek watershed and watersheds 1 and 2]

\begin{tabular}{|c|c|c|c|c|c|c|}
\hline \multirow{2}{*}{ Event date } & \multirow{2}{*}{$\begin{array}{l}\text { Rainfall } \\
\text { (inches) }\end{array}$} & \multicolumn{4}{|c|}{$\begin{array}{c}\text { Runoff } \\
\text { (acre-feet) }\end{array}$} & \multirow{2}{*}{$\begin{array}{l}\text { Runoff coefficient } \\
\text { (total study area) }\end{array}$} \\
\hline & & $\begin{array}{c}\text { Moody Creek } \\
\text { watershed }\end{array}$ & Watershed 1 & Watershed 2 & $\begin{array}{c}\text { Total study } \\
\text { area }\end{array}$ & \\
\hline $03 / 13-16 / 00$ & 6.11 & ${ }^{1} 685$ & ${ }^{1} 8.6$ & ${ }^{1} 5.8$ & ${ }^{1} 699$ & ${ }^{1} 0.096$ \\
\hline $10 / 06 / 00$ & 4.67 & 19.4 & .80 & 0 & 20.2 & .004 \\
\hline $10 / 10-12 / 00$ & 1.89 & 10.9 & .30 & 0 & 11.2 & .005 \\
\hline $11 / 04-08 / 00$ & 2.53 & 36.2 & 1.1 & .60 & 37.9 & .013 \\
\hline $11 / 16-19 / 00$ & 1.94 & 81.2 & 1.6 & 0 & 82.8 & .036 \\
\hline $12 / 26 / 00$ & .88 & 1.7 & 0 & 0 & 1.7 & .002 \\
\hline 01/10-20/01 & 2.61 & 256 & 2.2 & .80 & 259 & .083 \\
\hline 08/28-09/01/01 & 7.46 & 1,270 & 7.6 & 9.2 & 1,290 & .145 \\
\hline $11 / 16-17 / 01$ & 4.17 & ${ }^{2} 402$ & 1.8 & 2.4 & ${ }^{2} 406$ & ${ }^{2} .082$ \\
\hline Total $^{3}$ (nine events) & 32.26 & 2,760 & 24.0 & 18.8 & 2,800 & .073 \\
\hline Total $^{3}$ 2000-2001 & 61.47 & 2,760 & 24.0 & 18.8 & 2,800 & .038 \\
\hline
\end{tabular}

Table 2. Concentrations of nutrients in rainfall samples, 2000-2001

[Rainfall in inches; concentrations in milligrams per liter; <, less than]

\begin{tabular}{|c|c|c|c|c|c|}
\hline \multirow{2}{*}{ Constituent } & \multicolumn{5}{|c|}{ Rainfall event date } \\
\hline & $6 / 9 / 00$ & $8 / 15 / 00$ & $10 / 06 / 00$ & $08 / 28 / 01$ & $8 / 30 / 01$ \\
\hline Rainfall & 0.23 & 0.75 & 4.34 & 1.55 & 1.89 \\
\hline Nitrogen, ammonia, dissolved & .11 & .064 & .055 & .016 & .060 \\
\hline Nitrogen, ammonia + organic, dissolved & .25 & .070 & $<.05$ & $<.05$ & .060 \\
\hline Nitrogen, ammonia + organic, total & .18 & .090 & .060 & .050 & .090 \\
\hline Nitrogen, nitrite + nitrate, dissolved & .11 & .11 & .070 & .020 & .060 \\
\hline Nitrogen, nitrite, dissolved & .001 & .002 & $<.001$ & $<.001$ & $<.001$ \\
\hline Nitrogen, total & .35 & .20 & .13 & .070 & .12 \\
\hline Phosphorus, orthophosphate, dissolved & .003 & .001 & $<.001$ & $<.007$ & $<.007$ \\
\hline Phosphorus, dissolved & .006 & $<.006$ & $<.006$ & $<.006$ & $<.006$ \\
\hline Phosphorus, total & .011 & $<.008$ & $<.004$ & $<.004$ & .003 \\
\hline
\end{tabular}

\section{Nutrients}

Concentrations of selected nutrients analyzed in each sample are listed in table 2; summary statistics computed for the nutrient concentrations are listed in table 3. Most of the rainfall nitrogen is in the form of dissolved ammonia and dissolved nitrate, which were detected in all of the samples. Phosphorus was detected in less than one-half of the samples and at relatively small concentrations (near laboratory minimum reporting levels). 
Table 3. Summary statistics of selected nutrient concentrations in rainfall samples, 2000-2001

[Rainfall in inches; concentrations in milligrams per liter; --, not determined; <, less than]

\begin{tabular}{lccccc}
\hline \multicolumn{1}{c}{ Constituent } & $\begin{array}{c}\text { No. of } \\
\text { samples }\end{array}$ & Mean & Median & Minimum & Maximum \\
\hline Rainfall (inches) & 5 & 1.75 & 1.55 & 0.23 & 4.34 \\
Nitrogen, ammonia, dissolved & 5 & .060 & .060 & .016 & .11 \\
Nitrogen, ammonia + organic, dissolved & 5 & -- & $<.1$ & $<.05$ & .25 \\
Nitrogen, ammonia + organic, total & 5 & .090 & .090 & .050 & .18 \\
Nitrogen, nitrite + nitrate, dissolved & 5 & .074 & .068 & .020 & .11 \\
Nitrogen, nitrite, dissolved & 5 & $<.001$ & $<.001$ & $<.001$ & .002 \\
Nitrogen, total & 5 & .174 & .13 & .07 & .35 \\
Orthophosphate phosphorus, dissolved & 5 & -- & $<.004$ & $<.001$ & .003 \\
Phosphorus, dissolved & 5 & $<.006$ & $<.006$ & $<.006$ & .006 \\
Phosphorus, total & 5 & -- & $<.004$ & $<.004$ & .011 \\
\hline
\end{tabular}

\section{Rainfall Deposition of Nitrogen}

The deposition of rainfall constituents (in pounds per acre) can be defined as the product of the EMC and the rainfall volume. For rainfall events during which rainfall samples were collected and analyzed, thus providing EMCs, daily deposition of total nitrogen was computed as

$$
\mathrm{D}_{\mathrm{TN}}=\mathrm{C}_{\mathrm{TN}} \times \mathrm{R} \times \mathrm{Cf},
$$

where

$$
\begin{aligned}
\mathrm{D}_{\mathrm{TN}}= & \text { daily deposition of total nitrogen, in pounds per } \\
& \text { acre; } \\
\mathrm{C}_{\mathrm{TN}}= & \text { total nitrogen rainfall EMC, in milligrams per } \\
& \text { liter; } \\
\mathrm{R}= & \text { daily rainfall, in inches; and } \\
\mathrm{Cf}= & \text { conversion factor of } 0.2266 .
\end{aligned}
$$

For unsampled rainfall events, for which nitrogen concentration data were not available, daily deposition of total nitrogen was estimated using regression equations that relate daily rainfall and daily nitrogen deposition. Regression equations from a previous study of rainfall deposition of nitrogen (Ockerman and Livingston, 1999) were modified using data from this study. The resulting equation is

$$
\mathrm{D}_{\mathrm{TN}}=0.038 \times \mathrm{R}^{0.586},
$$

where

$\mathrm{D}_{\mathrm{TN}}=$ estimated daily deposition of total nitrogen, in pounds per acre; and

$$
\mathrm{R}=\text { daily rainfall, in inches. }
$$

A comparison of total nitrogen deposition computed from sample analysis and estimated by regression is shown in figure 4.

The daily values for rainfall deposition of total nitrogen were aggregated to produce the monthly and annual totals for 2000-2001 listed in the following table.

Monthly and annual rainfall deposition of total nitrogen, 2000-2001

[In pounds per acre]

\begin{tabular}{rrrrrrrrrrrrrr}
\hline Year & Jan. & \multicolumn{1}{c}{ Feb. } & \multicolumn{1}{c}{ Mar. } & \multicolumn{1}{c}{ Apr. } & May & June & July & Aug. & Sept. & Oct. & Nov. & Dec. & Annual \\
\hline 2000 & \multicolumn{1}{c}{0.06} & 0.05 & \multicolumn{1}{c}{0.15} & \multicolumn{1}{c}{0.06} & 0.13 & 0.16 & 0.07 & 0.07 & 0.05 & 0.31 & 0.24 & 0.08 & 1.43 \\
2001 & .14 & .06 & .15 & .02 & .07 & .01 & .08 & .21 & .07 & .09 & .17 & .11 & 1.18 \\
\hline
\end{tabular}




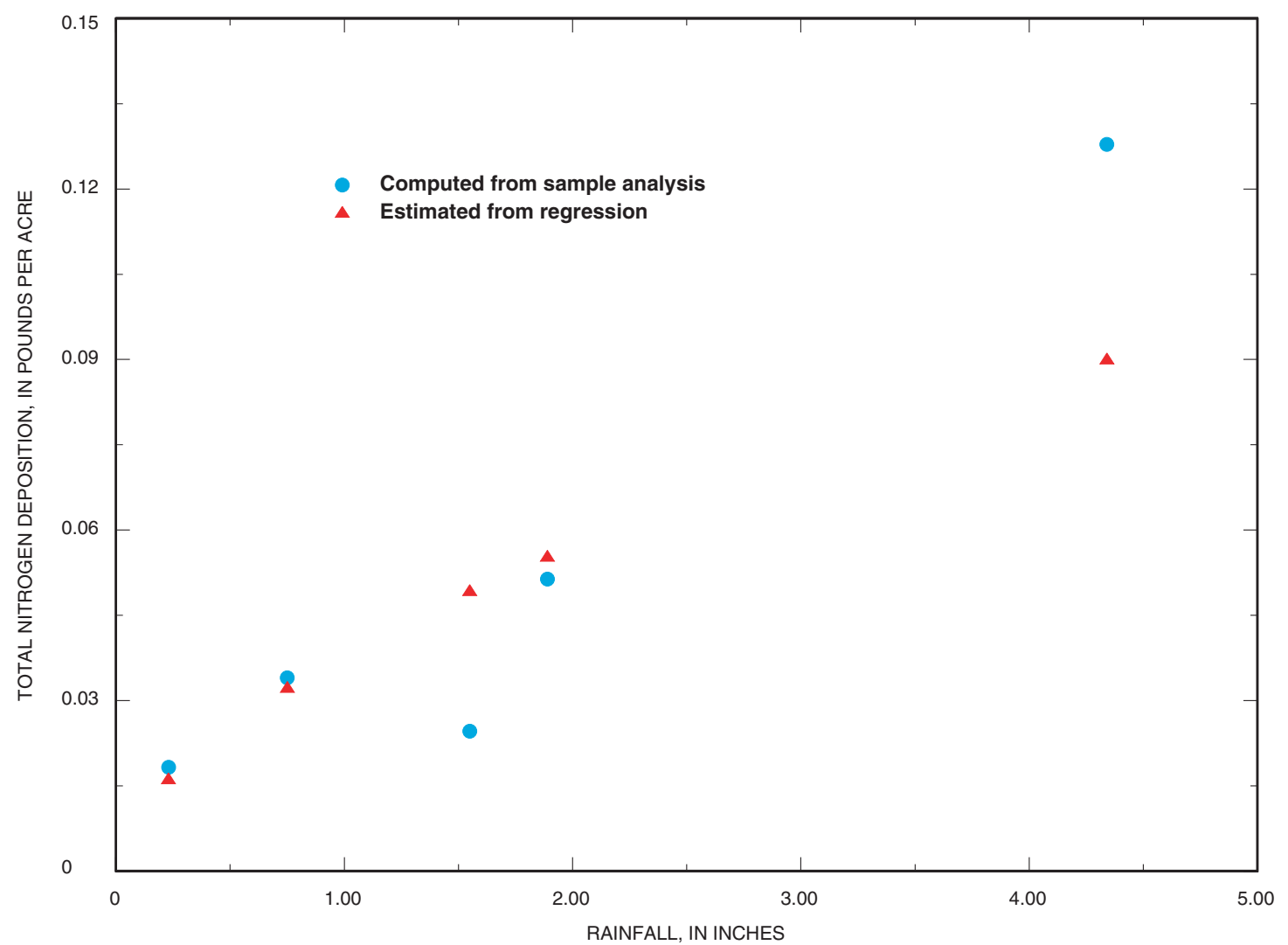

Figure 4. Comparison of computed and estimated (from regression) total nitrogen deposition for sampled rainfall events, June 2000-August 2001.

\section{Runoff}

During October 2000-November 2001, 10 runoff-event samples were collected among the three stations and analyzed for the constituents listed in the table below. The EMCs by site and event are listed in table 4 (at end of report).

Constituents analyzed in runoff samples, 2000-2001 [Y, sample collected and analyzed; --, not collected or analyzed]

\begin{tabular}{rccccc}
\hline $\begin{array}{c}\text { Sampling } \\
\text { site }\end{array}$ & Date & $\begin{array}{c}\text { Nutrients, } \\
\text { inorganic } \\
\text { ions }\end{array}$ & $\begin{array}{c}\text { Trace } \\
\text { ele- } \\
\text { ments }\end{array}$ & $\begin{array}{c}\text { Pesti- } \\
\text { cides }\end{array}$ & $\begin{array}{c}\text { Bac- } \\
\text { teria }\end{array}$ \\
\hline Moody Creek & $10 / 06 / 00$ & $\mathrm{Y}$ & $\mathrm{Y}$ & $\mathrm{Y}$ & $\mathrm{Y}$ \\
watershed & $01 / 11 / 01$ & $\mathrm{Y}$ & $\mathrm{Y}$ & $\mathrm{Y}$ & $\mathrm{Y}$ \\
& $08 / 30 / 01$ & $\mathrm{Y}$ & $\mathrm{Y}$ & $\mathrm{Y}$ & $\mathrm{Y}$ \\
& $11 / 16 / 01$ & $\mathrm{Y}$ & -- & -- & -- \\
Watershed 1 & $10 / 06 / 00$ & $\mathrm{Y}$ & $\mathrm{Y}$ & $\mathrm{Y}$ & $\mathrm{Y}$ \\
& $01 / 11 / 01$ & $\mathrm{Y}$ & $\mathrm{Y}$ & $\mathrm{Y}$ & $\mathrm{Y}$ \\
& $08 / 30 / 01$ & $\mathrm{Y}$ & $\mathrm{Y}$ & $\mathrm{Y}$ & $\mathrm{Y}$ \\
Watershed 2 & $11 / 16 / 01$ & $\mathrm{Y}$ & $\mathrm{Y}$ & -- & -- \\
& $08 / 30 / 01$ & $\mathrm{Y}$ & $\mathrm{Y}$ & $\mathrm{Y}$ & $\mathrm{Y}$ \\
& $11 / 16 / 01$ & $\mathrm{Y}$ & $\mathrm{Y}$ & $\mathrm{Y}$ & $\mathrm{Y}$ \\
\hline
\end{tabular}

Nutrients, Major Inorganic lons, and Trace Elements

Concentrations of selected nutrients, chloride, sulfate, and lead in runoff samples from the mixed agricultural watershed were compared to concentrations of the same constituents in runoff samples from the rangeland watersheds (fig. 5). Concentrations in samples from the mixed agricultural watershed generally were greater than concentrations in samples from the rangeland watersheds. The small number of samples from the two types of watersheds precluded the application of a statistical test (for example, Wilcoxon rank-sum) that could indicate whether concentrations differ significantly between the two types of watersheds.

Summary statistics of EMCs for nutrients, inorganic ions, and trace elements are listed in table 5 (at end of report). Because of the differences in land use and apparent differences in concentrations in samples from watersheds 1 and 2 compared with those from the Moody Creek watershed, statistics are presented for two groups of data. Data from watersheds 1 and 2 combined 

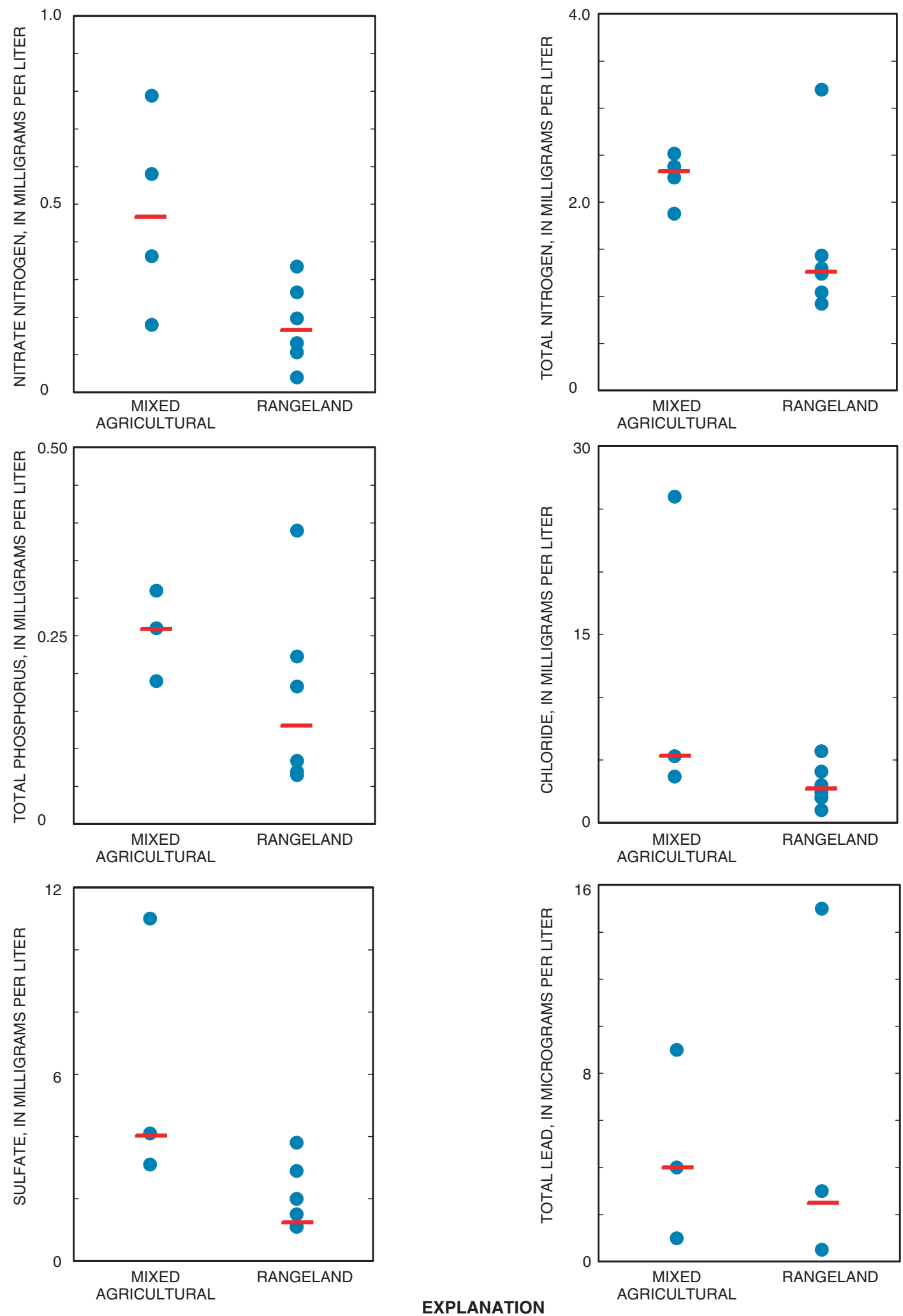

Event-mean concentration

EXPLANATION

Figure 5. Comparison of runoff concentrations for selected constituents between mixed agricultural watershed (Moody Creek watershed) and rangeland watersheds (watersheds 1 and 2), 2000-2001. 
are listed as rangeland, and data from Moody Creek are listed as mixed agricultural. The median EMCs for most constituents were larger in the mixed agricultural samples than in the rangeland samples.

\section{Pesticides}

Runoff samples were analyzed for a suite of 50 pesticides (Zaugg and others, 1995), many of which are not applied in the study area. Only three pesticides were detected in the samples-atrazine, deethylatrazine (a breakdown product of atrazine), and trifluralin. These three pesticides are not used on the wildlife refuge (watersheds 1 and 2) but are used on cropland in the upper Moody Creek watershed (Leroy Wolff, U.S. Department of Agriculture, Natural Resources Conservation Service, oral commun., 2000). Pesticides were detected in two of eight samples analyzed (Moody Creek and watershed 1 samples collected Nov. 16, 2001, were not analyzed for pesticides). Three detections of pesticides were at watershed 1, and two detections were at Moody Creek. No pesticides were detected at watershed 2. Four of the five detections were in the Jan. 11, 2001, runoff samples. All concentrations of pesticides detected are listed in the following table:

Concentrations of pesticides detected in runoff samples, 2000-2001

\begin{tabular}{ccccc}
\hline Pesticide & $\begin{array}{c}\text { Sampling } \\
\text { site }\end{array}$ & $\begin{array}{c}\text { Event } \\
\text { date }\end{array}$ & $\begin{array}{c}\text { Concen- } \\
\text { tration } \\
\text { (microgram } \\
\text { per liter) }\end{array}$ & $\begin{array}{c}\text { Laboratory } \\
\text { minimum } \\
\text { reporting } \\
\text { level } \\
\text { (microgram } \\
\text { per liter) }\end{array}$ \\
\hline Atrazine & Watershed 1 & $01 / 11 / 01$ & 0.006 & 0.007 \\
& Watershed 1 & $08 / 30 / 01$ & .007 & .007 \\
Deethyl- & $\begin{array}{c}\text { Moody Creek } \\
\text { atrazine }\end{array}$ & $01 / 11 / 01$ & .01 & .007 \\
Trifluralin & $\begin{array}{c}\text { Moody Creek } \\
\text { watershed }\end{array}$ & $01 / 11 / 01$ & .004 & .009 \\
\hline & Watershed 1 & $01 / 11 / 01$ & .003 & .009 \\
\hline
\end{tabular}

\footnotetext{
${ }^{1}$ Some reported concentrations were less than the laboratory minimum reporting level. In these instances, analytical results confirm identification of the compound, and the reported concentrations are considered estimates.
}

The largest reported pesticide concentration was 0.01 microgram per liter of deethylatrazine from the Moody Creek sample in January 2001. No guideline for protection of aquatic life has been established for deethylatrazine in the Texas State Water Quality Standards (TSWQS) (Texas Natural Resource Conservation Commission, 2002).

\section{Bacteria}

Results of bacteria analyses in runoff samples are listed in table 6 (at end of report). The runoff samples were collected as discrete grab samples and do not represent EMCs. Because the number of samples is small and the concentrations are not EMCs, statistical comparisons of concentrations among watersheds are not considered appropriate. Concentrations from all three watersheds were grouped together, and summary statistics were computed (table 7, at end of report). Table 7 also lists TSWQS for the tidal reach of the Aransas River, which is the receiving water body for runoff from the study area watersheds.

All fecal coliform densities and most E. coli densities were greater than the recommended TSWQS for freshwater and saltwater receiving waters. The receiving waters (tidal segment of the Aransas River and Copano Bay) for the study area watersheds are saltwater. The primary indicator bacteria for saltwater is enterococcus, which was not analyzed in any of the samples.

TSWQS for bacteria are appropriate for actual receiving waters and do not apply strictly to samples collected at locations above the point where runoff enters the receiving water body (as in this study). Also, because runoff and associated large bacteria densities represent a very brief and infrequent condition, the effect on downstream waters is not known. However, the relatively large bacteria densities (compared to TSWQS) indicate that runoff from these watersheds is a potential source of bacteria to receiving streams and bays.

Bacteria densities in samples from the agricultural and rangeland watersheds also were compared to bacteria densities from an area of urban land uses. As part of the Corpus Christi National Pollutant Discharge Elimination System permit application (City of Corpus Christi, 1993), 30 stormwater-runoff samples were collected from five locations (residential, commercial, and industrial watersheds) during November 1992-April 1993. Grab samples were collected and analyzed for fecal coliform and fecal streptococcus bacteria. Mean and median bacteria densities were 40,100 and 30,500 colonies per 100 milliliters for fecal coliforms and 
4,200,000 and 125,000 colonies per 100 milliliters for fecal streptococci. Mean and median bacteria densities for the urban watersheds were substantially larger than those for the agricultural and rangeland watersheds.

\section{Loads and Yields}

The load of a constituent in runoff is the mass of the given constituent transported past a site during a specified time. Daily runoff loads were computed for selected constituents for each watershed from runoff and concentration data. For runoff events that were sampled and for which EMCs were determined, the daily constituent load at a particular site is

$$
\mathrm{L}_{\mathrm{n}}=\mathrm{EMC} \times \mathrm{RV} \times \mathrm{Cf},
$$

where

$\mathrm{L}_{\mathrm{n}}=$ constituent load, in pounds per day at site ${ }_{\mathrm{n}} ;$

EMC = event-mean concentration during runoff event, in milligrams per liter;

$\mathrm{RV}=$ runoff volume, in acre-feet per day; and

$\mathrm{Cf}=$ conversion factor, 2.719 for EMCs in milligrams per liter.

For unsampled events, median EMCs for samples collected during the study were used in equation 3 to compute daily loads. Daily loads were summed to compute monthly and annual loads. Monthly and annual loads, by watershed, for selected constituents are shown in table 8 (at end of report).

Constituent yield, a measure of the loadproducing characteristics of a watershed, is computed by dividing the load by the drainage area of the watershed:

$$
\mathrm{Y}=\mathrm{L} / \mathrm{DA} \text {, }
$$

where

$\mathrm{Y}=$ constituent yield, in pounds per acre per month (or year);

$\mathrm{L}=$ constituent load exiting the watershed in pounds per month (or year); and

DA = contributing area of the watershed, in acres.

The average annual yields of selected constituents, by watershed, are listed in the following table.
Average annual yields of selected constituents in runoff from study area watersheds, 2000-2001

[In pounds per acre per year]

\begin{tabular}{ccccc}
\hline Constituent & $\begin{array}{c}\text { Water- } \\
\text { shed 1 }\end{array}$ & $\begin{array}{c}\text { Water- } \\
\text { shed 2 }\end{array}$ & $\begin{array}{c}\text { Total, } \\
\text { rangeland } \\
\text { (water- } \\
\text { sheds } \\
\text { 1 and 2) }\end{array}$ & $\begin{array}{c}\text { Mixed } \\
\text { agricul- } \\
\text { tural } \\
\text { (Moody } \\
\text { Creek) }\end{array}$ \\
\hline $\begin{array}{c}\text { Nitrogen, nitrite }+ \\
\text { nitrate, dissolved }\end{array}$ & 0.047 & 0.015 & 0.022 & 0.090 \\
Nitrogen, total & .39 & .16 & .21 & .57 \\
Phosphorus, total & .036 & .019 & .023 & .076 \\
Suspended solids & 17 & 32 & 28 & 76 \\
\hline
\end{tabular}

Runoff yields generally were greater at watershed 1 than at watershed 2. Runoff yields from Moody Creek (agricultural watershed) were greater than the total yields from the rangeland watersheds. The 2000-2001 average annual yields of total nitrogen in runoff exiting the agricultural watershed ( 0.57 pound per acre) and exiting the rangeland watersheds ( 0.21 pound per acre) were less than the 2000-2001 average annual rainfall deposition of total nitrogen (1.3 pounds per acre) listed in the table in the section "Rainfall Deposition of Nitrogen."

Loads and yields were not computed for bacteria because bacteria densities do not represent EMCs. Loads and yields also were not computed for pesticides because pesticides were not detected in most samples, and those pesticides detected were at very small concentrations.

\section{SUMMARY}

During 2000-2001, rainfall and runoff were monitored at a NOAA weather station and at three streamflow-gaging and water-quality sampling stations in agricultural and rangeland areas in San Patricio County in the Coastal Bend area of South Texas. Five rainfall samples were collected and analyzed for selected nutrients, and 10 runoff-event composited samples were collected at the streamflow stations during runoff events and analyzed for selected nutrients, major ions, trace elements, and pesticides. Grab samples also were collected during runoff events and analyzed for bacteria.

Rainfall and runoff data and water-quality analyses were used primarily to estimate rainfall total nitrogen loads to the study area watersheds, to compare runoff concentrations from one mixed agricultural watershed and two rangeland watersheds, and to 
compute runoff loads and yields of selected constituents entering the receiving bays and estuaries from these watersheds.

Study area rainfall during 2000 and 2001 was 33.27 and 28.20 inches, respectively, less than the longterm average annual of 36.31 inches. Rainfall in the study area was below average for 16 of the 24 months. Because of the combination of soils, vegetation, mild land surface slopes, and frequent dry periods, runoff from the study area occurred only after heavy rains. Nine runoff events occurred, producing relatively small runoff volumes. To illustrate how the hydrology of the area is dominated by extreme events, the three largest runoff events resulted in 29 percent of the total rainfall and produced 86 percent of the total runoff for 20002001 . Total runoff from the study area watersheds during 2000-2001 was 2.46 inches (2,800 acre-feet); the regional average is about 2 inches per year.

Runoff from the larger mixed agricultural watershed generally had larger concentrations of selected nutrients, major ions, and trace elements, compared with runoff from the rangeland watersheds. Also, the 2000-2001 average annual yields (pounds per acre) of selected constituents in runoff exiting the mixed agricultural watershed were larger than yields exiting the rangeland watersheds. For example, total phosphorus yield from the mixed agricultural watershed was 0.072 pound per acre per year compared with 0.023 pound per acre per year from the rangeland watersheds. The suspended solids yield from the rangeland watersheds averaged 28 pounds per acre per year, which was much smaller than the 76 pounds per acre per year from the mixed agricultural watershed.

Rainfall deposition is a major source of nitrogen delivered to the study area. Rainfall nitrogen (mostly ammonia and nitrate) exceeded the runoff yield. The average annual rainfall deposition of total nitrogen on the study area watersheds was 1.3 pounds per acre. In contrast, an average annual yield of 0.57 and 0.21 pound per acre of total nitrogen in runoff exited the mixed agricultural watershed and the rangeland watersheds, respectively.

Pesticides were detected in two of eight runoff samples (two runoff samples were not analyzed for pesticides). All of the detections occurred at Moody Creek and watershed 1 . Three pesticides (atrazine, deethylatrazine, and trifluralin) were detected in very small concentrations. All but one pesticide detection was reported at or below the laboratory minimum reporting level. The largest measured pesticide concentration was
0.01 microgram per liter of deethylatrazine (a breakdown product of atrazine) at Moody Creek during the January 2001 runoff event.

Bacteria in runoff is a potential water-quality concern. Although bacteria densities in the study area watersheds are much smaller than concentrations in urban runoff, all densities of fecal coliform and E. coli from the agricultural watershed and the rangeland watersheds exceeded recommended TSWQS for receiving waters. Also, because runoff and associated large bacteria densities represent a very brief and infrequent condition, the effect on downstream waters is not known. However, the relatively large bacteria densities (compared to TSWQS), indicate that runoff from these watersheds is a potential source of bacteria to receiving streams and bays.

\section{REFERENCES}

Baird, F.C., Dybala, T.J., Jennings, Marshall, and Ockerman, D.J., 1996, Characterization of nonpoint sources and loadings to the Corpus Christi Bay National Estuary Program study area: Texas Natural Resource Conservation Commission, Corpus Christi Bay National Estuary Program CCBNEP-05, $226 \mathrm{p}$.

Buchanan, T.J., and Somers, W.P., 1969, Discharge measurements at gaging stations: U.S. Geological Survey Techniques of Water-Resources Investigations, book 3 , chap. A8, $65 \mathrm{p}$.

City of Corpus Christi, 1993, City of Corpus Christi part II NPDES permit application, wet weather sampling program-Executive summary: Corpus Christi, Tex., 16 p.

Drawe, D.L., 1997, Tailoring rangelands to enhance wildlife habitat-The Welder Wildlife Refuge experience: Accessed Feb. 5, 2002, at URL http://texnat.tamu.edu/symposia/SCULPTOR/28.htm

Kennedy, E.J., 1984, Discharge ratings at gaging stations: U.S. Geological Survey Techniques of Water-Resources Investigations, book 3, chap. A10, 59 p.

Ockerman, D.J., and Livingston, C.W., 1999, Nitrogen concentrations and deposition in rainfall at two sites in the Coastal Bend area, South Texas, 1996-98: U.S. Geological Survey Fact Sheet FS-146-99, 6 p.

Patino, Eduardo, and Ockerman, D.J., 1997, Computation of mean velocity in open channels using acoustic velocity meters: U.S. Geological Survey Open-File Report 97-220, $12 \mathrm{p}$.

Quenzer, A.M., Maidment, D.R., Hellweger, F.L., Eid, N.J., Ward, G.H., and Armstrong, N.E., 1998, Total loads and water quality in the Corpus Christi Bay system: Texas Natural Resource Conservation Commission, Corpus 
Christi Bay National Estuary Program CCBNEP-27, $226 \mathrm{p}$.

Rantz, S.E., and others, 1982, Measurement and computation of streamflow-Volume 1. Measurement of stage and discharge: U.S. Geological Survey Water-Supply Paper 2175, 284 p.

Soil Conservation Service, 1979, Soil survey, San Patricio County, Texas: U.S. Department of Agriculture, 122 p.

State of Texas, 2000, Site-specific uses and criteria for classified segments: Texas Administrative Code, Title 30, Part 1, Chap. 307, Rule 307.10, App. A.

Texas Natural Resource Conservation Commission, 1996, 1994 Regional assessment of water quality in the Nueces
Coastal Basins: Texas Natural Resource Conservation Commission, Agency Studies AS-035, 567 p.

2002, Texas Surface Water Quality Standards:

Accessed May 6, 2002, at URL

http://www.tnrcc.state.tx.us/permitting/waterperm/ wqstand/index.html

Zaugg, S.D., Sandstrom, M.W., Smith, S.G., and Fehlberg, K.M., 1995, Methods of analysis by the U.S. Geological Survey National Water Quality Laboratory-Determination of pesticides in water by $\mathrm{C}-18$ solid-phase extraction and capillary-column gas chromatography/ mass spectrometry with selected-ion monitoring: U.S. Geological Survey Open-File Report 95-181, 60 p. 
Table 4. Event-mean concentrations for selected properties and constituents in runoff samples, 2000-2001

$[\mathrm{mg} / \mathrm{L}$, milligrams per liter; --, not measured; $\mu \mathrm{S} / \mathrm{cm}$, microsiemens per centimeter at 25 degrees Celsius; <, less than; $\mu \mathrm{g} / \mathrm{L}$, micrograms per liter]

\begin{tabular}{|c|c|c|c|c|c|c|c|c|c|c|}
\hline \multirow{3}{*}{ Constituent } & \multicolumn{4}{|c|}{ Moody Creek watershed } & \multicolumn{4}{|c|}{ Watershed 1} & \multirow{2}{*}{\multicolumn{2}{|c|}{$\begin{array}{c}\text { Watershed } 2 \\
\text { Event date }\end{array}$}} \\
\hline & & Ever & date & & & Even & date & & & \\
\hline & $10 / 06 / 00$ & $01 / 11 / 01$ & 08/30/01 & 11/16/01 & $10 / 06 / 00$ & $01 / 11 / 01$ & 08/30/01 & 11/16/01 & $08 / 30 / 01$ & $11 / 16 / 01$ \\
\hline$\overline{\text { Dissolved solids (mg/L) }}$ & 37 & 80 & 56 & -- & 83 & 70 & 62 & 84 & 30 & 116 \\
\hline Suspended solids $(\mathrm{mg} / \mathrm{L})$ & 38 & 144 & 444 & -- & 166 & 13 & 18 & 22 & 790 & 128 \\
\hline Specific conductance $(\mu \mathrm{S} / \mathrm{cm})$ & 191 & 100 & 102 & -- & 118 & 85 & 51 & 57 & 56 & 112 \\
\hline Alkalinity $\left(\mathrm{mg} / \mathrm{L}\right.$ as $\left.\mathrm{CaCO}_{3}\right)$ & 54 & -- & -- & -- & -- & -- & -- & -- & -- & -- \\
\hline Chemical oxygen demand $(\mathrm{mg} / \mathrm{L})$ & 36 & 49 & 32 & -- & 35 & 37 & 31 & 29 & $<10$ & 26 \\
\hline $\mathrm{pH}$ (standard units) & 7.9 & 7.5 & 7.6 & -- & 7.1 & 6.9 & 6.9 & 7.2 & 7.7 & 7.6 \\
\hline Nitrogen, ammonia, dissolved (mg/L) & .12 & .04 & .03 & .03 & .07 & .02 & .04 & .02 & .05 & $<.04$ \\
\hline Nitrogen, ammonia + organic, dissolved $(\mathrm{mg} / \mathrm{L})$ & .91 & .98 & .57 & .63 & .71 & .90 & .72 & .70 & .28 & .64 \\
\hline Nitrogen, ammonia + organic, total $(\mathrm{mg} / \mathrm{L})$ & 1.7 & 1.8 & 1.7 & 1.9 & 1.0 & 1.2 & .79 & .94 & 3.0 & 1.1 \\
\hline Nitrogen, nitrite + nitrate, dissolved $(\mathrm{mg} / \mathrm{L})$ & .82 & .58 & .18 & .36 & .27 & .04 & .13 & .11 & .20 & .33 \\
\hline Nitrogen, nitrite, dissolved (mg/L) & .03 & .01 & .01 & .01 & .01 & .004 & .007 & .005 & .02 & .02 \\
\hline Phosphorus, orthophosphate, dissolved (mg/L) & .10 & .04 & .09 & .06 & .15 & .01 & .03 & .13 & .05 & .08 \\
\hline Phosphorus, dissolved (mg/L) & .13 & .07 & .11 & .09 & .19 & .04 & .06 & .03 & .06 & .11 \\
\hline Phosphorus, total (mg/L) & -- & .19 & .31 & .26 & .22 & .07 & .08 & .06 & .39 & .18 \\
\hline Calcium, dissolved (mg/L) & 12 & 8.3 & 10 & -- & 1.4 & 4.9 & 3.9 & 4.0 & 5.1 & 13 \\
\hline Magnesium, dissolved (mg/L) & 2.0 & 1.4 & 1.3 & -- & .44 & 1.4 & 1.1 & 1.3 & .70 & 1.9 \\
\hline Sodium, dissolved $(\mathrm{mg} / \mathrm{L})$ & 16 & 5.1 & 5.8 & -- & .91 & 4.3 & 2.4 & 1.7 & 1.3 & 3.5 \\
\hline Potassium, dissolved (mg/L) & 5.1 & 5.6 & 4.2 & -- & 7.1 & 6.2 & 4.9 & 6.0 & 2.7 & 6.1 \\
\hline Chloride, dissolved (mg/L) & 26 & 5.3 & 3.7 & -- & 2.0 & 5.7 & 2.4 & 2.2 & 1.0 & 4.1 \\
\hline Sulfate, dissolved (mg/L) & 11 & 4.1 & 3.1 & -- & 1.1 & 3.8 & 1.5 & 1.7 & 1.1 & 2.9 \\
\hline Fluoride, dissolved (mg/L) & $<.16$ & $<.2$ & $<.2$ & -- & .16 & $<.2$ & $<.2$ & .20 & $<.2$ & $<.1$ \\
\hline Silica, dissolved $(\mathrm{mg} / \mathrm{L})$ & 4.4 & 7.6 & 6.0 & -- & 2.0 & 8.2 & 5.6 & .70 & 5.2 & 19 \\
\hline Cadmium, total $(\mu \mathrm{g} / \mathrm{L})$ & $<.1$ & .1 & .12 & -- & $<.1$ & $<.1$ & $<.1$ & $<.1$ & .24 & $<.1$ \\
\hline Copper, total $(\mu \mathrm{g} / \mathrm{L})$ & $<20$ & $<20$ & $<20$ & -- & $<20$ & $<20$ & $<20$ & $<10$ & $<20$ & 7 \\
\hline Iron, dissolved $(\mu \mathrm{g} / \mathrm{L})$ & 22 & 40 & 40 & -- & 24 & 30 & 50 & 30 & $<10$ & $<10$ \\
\hline Lead, total $(\mu \mathrm{g} / \mathrm{L})$ & $<1$ & 4 & 9 & -- & 3 & $<1$ & $<1$ & $<1$ & 15 & 3 \\
\hline Manganese, dissolved $(\mu \mathrm{g} / \mathrm{L})$ & 16 & 7.0 & 3.4 & -- & 6.2 & $<3$ & 3.1 & $<2$ & $<3$ & $<2$ \\
\hline
\end{tabular}


Table 4. Event-mean concentrations for selected properties and constituents in runoff samples, 2000-2001-Continued

\begin{tabular}{|c|c|c|c|c|c|c|c|c|c|c|c|}
\hline \multirow{3}{*}{\multicolumn{2}{|c|}{ 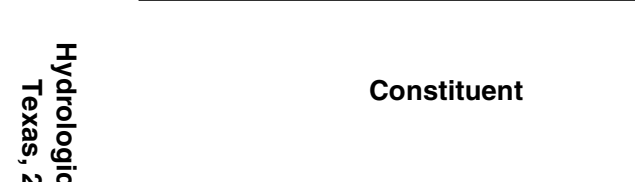 }} & \multicolumn{4}{|c|}{ Moody Creek watershed } & \multicolumn{4}{|c|}{ Watershed 1} & \multirow{2}{*}{\multicolumn{2}{|c|}{$\frac{\text { Watershed } 2}{\text { Event date }}$}} \\
\hline & & \multicolumn{4}{|c|}{ Event date } & \multicolumn{4}{|c|}{ Event date } & & \\
\hline & & $10 / 06 / 00$ & $01 / 11 / 01$ & $08 / 30 / 01$ & $11 / 16 / 01$ & $10 / 06 / 00$ & $01 / 11 / 01$ & $08 / 30 / 01$ & $11 / 16 / 01$ & 08/30/01 & $11 / 16 / 01$ \\
\hline ㅇํㅇ & Mercury, total $(\mu \mathrm{g} / \mathrm{L})$ & $<0.14$ & $<0.1$ & 0.02 & -- & $<0.14$ & $<0.1$ & $<0.1$ & 0.01 & 0.02 & 0.01 \\
\hline 느ㅇㅡㅡㄹ & Nickel, total $(\mu \mathrm{g} / \mathrm{L})$ & $<2$ & 2 & 5 & -- & 2 & $<2$ & 1 & $<2$ & 8 & 2 \\
\hline$=\frac{0}{0}$ & Zinc, total $(\mu \mathrm{g} / \mathrm{L})$ & $<31$ & 17 & $<31$ & -- & 17 & $<31$ & $<31$ & $<25$ & -- & 14 \\
\hline$\stackrel{2}{2}$ & Oil \& grease, total recoverable $(\mathrm{mg} / \mathrm{L})$ & 2 & $<1$ & -- & $<7$ & 1 & $<1$ & $<1$ & 6 & -- & 4 \\
\hline$\stackrel{0}{0}$ & Acetochlor $(\mu \mathrm{g} / \mathrm{L})$ & $<.002$ & $<.002$ & $<.002$ & -- & $<.002$ & $<.002$ & $<.002$ & -- & $<.002$ & $<.002$ \\
\hline 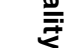 & Alpha-HCH $(\mu \mathrm{g} / \mathrm{L})$ & $<.005$ & $<.005$ & $<.005$ & -- & $<.005$ & $<.005$ & $<.005$ & -- & $<.005$ & $<.005$ \\
\hline$\stackrel{\circ}{\stackrel{9}{2}}$ & Atrazine $(\mu \mathrm{g} / \mathrm{L})$ & $<.007$ & $<.007$ & $<.007$ & -- & $<.007$ & .006 & .007 & -- & $<.007$ & $<.007$ \\
\hline 赵. & Deethylatrazine $(\mu \mathrm{g} / \mathrm{L})$ & $<.006$ & .01 & $<.006$ & -- & $<.006$ & $<.006$ & $<.006$ & -- & $<.006$ & $<.006$ \\
\hline$\stackrel{\vec{\jmath}}{=}$ & Alachlor $(\mu \mathrm{g} / \mathrm{L})$ & $<.002$ & $<.002$ & $<.002$ & -- & $<.002$ & $<.002$ & $<.002$ & -- & $<.002$ & $<.002$ \\
\hline 气 & Azinphos-methyl $(\mu \mathrm{g} / \mathrm{L})$ & $<.05$ & $<.05$ & $<.05$ & -- & $<.05$ & $<.05$ & $<.05$ & -- & $<.05$ & $<.05$ \\
\hline$\stackrel{\mathscr{C}}{0}$ & Benfluralin $(\mu \mathrm{g} / \mathrm{L})$ & $<.01$ & $<.01$ & $<.01$ & -- & $<.01$ & $<.01$ & $<.01$ & -- & $<.01$ & $<.01$ \\
\hline 3 & Butylate $(\mu \mathrm{g} / \mathrm{L})$ & $<.02$ & $<.02$ & $<.02$ & -- & $<.02$ & $<.02$ & $<.02$ & -- & $<.02$ & $<.02$ \\
\hline 茞 & Carbofuran $(\mu \mathrm{g} / \mathrm{L})$ & $<.028$ & $<.028$ & $<.028$ & -- & $<.028$ & $<.028$ & $<.028$ & -- & $<.028$ & $<.028$ \\
\hline$\stackrel{\Rightarrow}{\rightleftarrows}$ & Carbaryl $(\mu \mathrm{g} / \mathrm{L})$ & $<.04$ & $<.04$ & $<.04$ & -- & $<.04$ & $<.04$ & $<.04$ & -- & $<.04$ & $<.04$ \\
\hline$\vec{b}$ & Carbofuran $(\mu \mathrm{g} / \mathrm{L})$ & $<.02$ & $<.02$ & $<.02$ & -- & $<.02$ & $<.02$ & $<.02$ & -- & $<.02$ & $<.02$ \\
\hline ถั? & Chlorpyrifos $(\mu \mathrm{g} / \mathrm{L})$ & $<.005$ & $<.005$ & $<.005$ & -- & $<.005$ & $<.005$ & $<.005$ & -- & $<.005$ & $<.005$ \\
\hline$\overline{\vec{c}}$ & Cyanazine $(\mu \mathrm{g} / \mathrm{L})$ & $<.018$ & $<.018$ & $<.018$ & -- & $<.018$ & $<.018$ & $<.018$ & -- & $<.018$ & $<.018$ \\
\hline$\frac{1}{2}$ & 2,6-Diethylaniline $(\mu \mathrm{g} / \mathrm{L})$ & $<.002$ & $<.002$ & $<.002$ & -- & $<.002$ & $<.002$ & $<.002$ & -- & $<.002$ & $<.002$ \\
\hline$\frac{2}{p 0}$ & DCPA $(\mu \mathrm{g} / \mathrm{L})$ & $<.003$ & $<.003$ & $<.003$ & -- & $<.003$ & $<.003$ & $<.003$ & -- & $<.003$ & $<.003$ \\
\hline 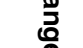 & Diazinon $(\mu \mathrm{g} / \mathrm{L})$ & $<.005$ & $<.005$ & $<.005$ & -- & $<.005$ & $<.005$ & $<.005$ & -- & $<.005$ & $<.005$ \\
\hline$\frac{10}{20}$ & Dieldrin $(\mu \mathrm{g} / \mathrm{L})$ & $<.005$ & $<.005$ & $<.005$ & -- & $<.005$ & $<.005$ & $<.005$ & -- & $<.005$ & $<.005$ \\
\hline 2 & Disulfoton $(\mu \mathrm{g} / \mathrm{L})$ & $<.02$ & $<.02$ & $<.02$ & -- & $<.02$ & $<.02$ & $<.02$ & -- & $<.02$ & $<.02$ \\
\hline 胥 & EPTC $(\mu \mathrm{g} / \mathrm{L})$ & $<.004$ & $<.004$ & $<.004$ & -- & $<.004$ & $<.004$ & $<.004$ & -- & $<.004$ & $<.004$ \\
\hline $\begin{array}{l}\mathbf{E} \\
\infty\end{array}$ & Ethalfluralin $(\mu \mathrm{g} / \mathrm{L})$ & $<.009$ & $<.009$ & $<.009$ & -- & $<.009$ & $<.009$ & $<.009$ & -- & $<.009$ & $<.009$ \\
\hline 气ับ & Ethoprop $(\mu \mathrm{g} / \mathrm{L})$ & $<.005$ & $<.005$ & $<.005$ & -- & $<.005$ & $<.005$ & $<.005$ & -- & $<.005$ & $<.005$ \\
\hline$\stackrel{\sharp}{\rightleftarrows}$ & Fonofos $(\mu \mathrm{g} / \mathrm{L})$ & $<.01$ & $<.01$ & $<.01$ & -- & $<.01$ & $<.01$ & $<.01$ & -- & $<.01$ & $<.01$ \\
\hline$\frac{\Omega}{0}$ & Gamma-HCH $(\mu \mathrm{g} / \mathrm{L})$ & $<.004$ & $<.004$ & $<.004$ & -- & $<.004$ & $<.004$ & $<.004$ & -- & $<.004$ & $<.004$ \\
\hline 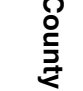 & Linuron $(\mu \mathrm{g} / \mathrm{L})$ & $<.0035$ & $<.035$ & $<.035$ & -- & $<.0035$ & $<.035$ & $<.035$ & -- & $<.035$ & $<.035$ \\
\hline
\end{tabular}


Table 4. Event-mean concentrations for selected properties and constituents in runoff samples, 2000-2001-Continued

\begin{tabular}{|c|c|c|c|c|c|c|c|c|c|c|}
\hline \multirow{3}{*}{ Constituent } & \multicolumn{4}{|c|}{ Moody Creek watershed } & \multicolumn{4}{|c|}{ Watershed 1} & \multirow{2}{*}{\multicolumn{2}{|c|}{$\begin{array}{c}\text { Watershed } 2 \\
\text { Event date }\end{array}$}} \\
\hline & \multicolumn{4}{|c|}{ Event date } & \multicolumn{4}{|c|}{ Event date } & & \\
\hline & $10 / 06 / 00$ & $01 / 11 / 01$ & 08/30/01 & $11 / 16 / 01$ & $10 / 06 / 00$ & $01 / 11 / 01$ & 08/30/01 & $11 / 16 / 01$ & 08/30/01 & $11 / 16 / 01$ \\
\hline Malathion $(\mu \mathrm{g} / \mathrm{L})$ & $<0.027$ & $<0.027$ & $<0.027$ & -- & $<0.027$ & $<0.027$ & $<0.027$ & -- & $<0.027$ & $<0.027$ \\
\hline Methyl parathion $(\mu \mathrm{g} / \mathrm{L})$ & $<.006$ & $<.006$ & $<.006$ & -- & $<.006$ & $<.006$ & $<.006$ & -- & $<.006$ & $<.006$ \\
\hline Metalochlor $(\mu \mathrm{g} / \mathrm{L})$ & $<.013$ & $<.013$ & $<.013$ & -- & $<.013$ & $<.013$ & $<.013$ & -- & $<.013$ & $<.013$ \\
\hline Metribuzin $(\mu \mathrm{g} / \mathrm{L})$ & $<.006$ & $<.006$ & $<.006$ & -- & $<.006$ & $<.006$ & $<.006$ & -- & $<.006$ & $<.006$ \\
\hline Methomyl ( $\mu \mathrm{g} / \mathrm{L})$ & $<.017$ & $<.017$ & $<.017$ & -- & $<.017$ & $<.017$ & $<.017$ & -- & $<.017$ & $<.017$ \\
\hline Methiocarb ( $\mu \mathrm{g} / \mathrm{L})$ & $<.026$ & $<.026$ & $<.026$ & -- & $<.026$ & $<.026$ & $<.026$ & -- & $<.026$ & $<.026$ \\
\hline Molinate $(\mu \mathrm{g} / \mathrm{L})$ & $<.002$ & $<.002$ & $<.002$ & -- & $<.002$ & $<.002$ & $<.002$ & -- & $<.002$ & $<.002$ \\
\hline Napropamide $(\mu \mathrm{g} / \mathrm{L})$ & $<.007$ & $<.007$ & $<.007$ & -- & $<.007$ & $<.007$ & $<.007$ & -- & $<.007$ & $<.007$ \\
\hline Parathion $(\mu \mathrm{g} / \mathrm{L})$ & $<.007$ & $<.007$ & $<.007$ & -- & $<.007$ & $<.007$ & $<.007$ & -- & $<.007$ & $<.007$ \\
\hline$p, p^{\prime}-\mathrm{DDE}(\mu \mathrm{g} / \mathrm{L})$ & $<.002$ & $<.002$ & $<.002$ & -- & $<.002$ & $<.002$ & $<.002$ & -- & $<.002$ & $<.002$ \\
\hline Pebulate $(\mu \mathrm{g} / \mathrm{L})$ & $<.002$ & $<.002$ & $<.002$ & -- & $<.002$ & $<.002$ & $<.002$ & -- & $<.002$ & $<.002$ \\
\hline Pendimethalin $(\mu \mathrm{g} / \mathrm{L})$ & $<.01$ & $<.01$ & $<.01$ & -- & $<.01$ & $<.01$ & $<.01$ & -- & $<.01$ & $<.01$ \\
\hline Permethrin $(\mu \mathrm{g} / \mathrm{L})$ & $<.006$ & $<.006$ & $<.006$ & -- & $<.006$ & $<.006$ & $<.006$ & -- & $<.006$ & $<.006$ \\
\hline Phorate $(\mu \mathrm{g} / \mathrm{L})$ & $<.01$ & $<.01$ & $<.01$ & -- & $<.01$ & $<.01$ & $<.01$ & -- & $<.01$ & $<.01$ \\
\hline Prometon $(\mu \mathrm{g} / \mathrm{L})$ & $<.015$ & $<.015$ & $<.015$ & -- & $<.015$ & $<.015$ & $<.015$ & -- & $<.015$ & $<.015$ \\
\hline Pronamide $(\mu \mathrm{g} / \mathrm{L})$ & $<.008$ & $<.008$ & $<.008$ & -- & $<.008$ & $<.008$ & $<.008$ & -- & $<.008$ & $<.008$ \\
\hline Propanil ( $\mu \mathrm{g} / \mathrm{L})$ & $<.01$ & $<.01$ & $<.01$ & -- & $<.01$ & $<.01$ & $<.01$ & -- & $<.01$ & $<.01$ \\
\hline Propachlor $(\mu \mathrm{g} / \mathrm{L})$ & $<.01$ & $<.01$ & $<.01$ & -- & $<.01$ & $<.01$ & $<.01$ & -- & $<.01$ & $<.01$ \\
\hline Propargite $(\mu \mathrm{g} / \mathrm{L})$ & $<.023$ & $<.023$ & $<.023$ & -- & $<.023$ & $<.023$ & $<.023$ & -- & $<.023$ & $<.023$ \\
\hline Simazine $(\mu \mathrm{g} / \mathrm{L})$ & $<.01$ & $<.01$ & $<.01$ & -- & $<.01$ & $<.01$ & $<.01$ & -- & $<.01$ & $<.01$ \\
\hline Thiobencarb $(\mu \mathrm{g} / \mathrm{L})$ & $<.005$ & $<.005$ & $<.005$ & -- & $<.005$ & $<.005$ & $<.005$ & -- & $<.005$ & $<.005$ \\
\hline Tebuthiuron $(\mu \mathrm{g} / \mathrm{L})$ & $<.016$ & $<.016$ & $<.016$ & -- & $<.016$ & $<.016$ & $<.016$ & -- & $<.016$ & $<.016$ \\
\hline Terbacil $(\mu \mathrm{g} / \mathrm{L})$ & $<.34$ & $<.34$ & $<.34$ & -- & $<.34$ & $<.34$ & $<.34$ & -- & $<.34$ & $<.34$ \\
\hline Terbufos $(\mu \mathrm{g} / \mathrm{L})$ & $<.017$ & $<.017$ & $<.017$ & -- & $<.017$ & $<.017$ & $<.017$ & -- & $<.017$ & $<.017$ \\
\hline Triallate $(\mu \mathrm{g} / \mathrm{L})$ & $<.002$ & $<.002$ & $<.002$ & -- & $<.002$ & $<.002$ & $<.002$ & -- & $<.002$ & $<.002$ \\
\hline Trifluralin $(\mu \mathrm{g} / \mathrm{L})$ & $<.009$ & .004 & $<.009$ & -- & $<.009$ & .003 & $<.009$ & -- & $<.009$ & $<.009$ \\
\hline
\end{tabular}


Table 5. Summary statistics of event-mean concentrations for selected constituents in runoff samples, 2000-2001

\begin{tabular}{|c|c|c|c|c|c|c|c|c|c|c|}
\hline \multirow[b]{2}{*}{ Constituent } & \multicolumn{5}{|c|}{ Mixed agricultural (Moody Creek) } & \multicolumn{5}{|c|}{ Rangeland (watersheds 1 and 2) } \\
\hline & $\begin{array}{c}\text { No. of } \\
\text { samples }\end{array}$ & Mean & Median & Minimum & Maximum & $\begin{array}{c}\text { No. of } \\
\text { samples }\end{array}$ & Mean & Median & Minimum & Maximum \\
\hline Dissolved solids (mg/L) & 3 & 58 & 56 & 37 & 80 & 6 & 74 & 76 & 30 & 116 \\
\hline Suspended solids (mg/L) & 3 & 209 & 144 & 38 & 444 & 6 & 190 & 75 & 13 & 790 \\
\hline Specific conductance $(\mu \mathrm{S} / \mathrm{cm})$ & 3 & 131 & 102 & 100 & 191 & 6 & 80 & 71 & 51 & 118 \\
\hline Nitrogen, ammonia, dissolved (mg/L) & 4 & .06 & .04 & .03 & .12 & 6 & .04 & $<.04$ & $<.04$ & .07 \\
\hline Nitrogen, ammonia + organic, dissolved (mg/L) & 4 & .77 & .77 & .57 & .98 & 6 & .66 & .70 & .28 & .90 \\
\hline Nitrogen, ammonia + organic, total $(\mathrm{mg} / \mathrm{L})$ & 4 & 1.8 & 1.8 & 1.7 & 1.9 & 6 & 1.3 & 1.1 & .79 & 3.0 \\
\hline Nitrogen, nitrite + nitrate, dissolved $(\mathrm{mg} / \mathrm{L})$ & 4 & .48 & .47 & .18 & .82 & 6 & .18 & .16 & .04 & .33 \\
\hline Nitrogen, nitrite, dissolved (mg/L) & 4 & .02 & .01 & .01 & .03 & 6 & .01 & .01 & .004 & .02 \\
\hline Nitrogen, total (mg/L) & 4 & 2.3 & 2.3 & 1.9 & 2.5 & 6 & 1.5 & 1.3 & .92 & 3.2 \\
\hline Phosphorus, orthophosphate, dissolved (mg/L) & 4 & .07 & .08 & .04 & .10 & 6 & .06 & .04 & .01 & .15 \\
\hline Phosphorus, dissolved (mg/L) & 4 & .10 & .10 & .07 & .13 & 6 & .08 & .06 & .03 & .19 \\
\hline Phosphorus, total (mg/L) & 3 & .25 & .26 & .19 & .31 & 6 & .17 & .13 & .06 & .39 \\
\hline Calcium, dissolved (mg/L) & 3 & 10 & 10 & 8.3 & 12 & 6 & 5.3 & 4.5 & 1.4 & 13 \\
\hline Magnesium, dissolved (mg/L) & 3 & 1.6 & 1.4 & 1.3 & 2.0 & 6 & 1.1 & 1.2 & .44 & 1.9 \\
\hline Sodium, dissolved (mg/L) & 3 & 9.0 & 5.8 & 5.1 & 16 & 6 & 2.4 & 2.0 & .91 & 4.3 \\
\hline Potassium, dissolved (mg/L) & 3 & 5.0 & 5.1 & 4.2 & 5.6 & 6 & 5.5 & 6.1 & 2.7 & 7.1 \\
\hline Chloride, dissolved (mg/L) & 3 & 12 & 5.3 & 3.7 & 26 & 6 & 2.9 & 2.3 & 1.0 & 5.7 \\
\hline Sulfate, dissolved (mg/L) & 3 & 6.1 & 4.1 & 3.1 & 11 & 6 & 1.9 & 1.3 & 1.1 & 3.8 \\
\hline Cadmium, total $(\mu \mathrm{g} / \mathrm{L})$ & 3 & -- & .1 & $<.1$ & .12 & 6 & -- & $<.1$ & $<.1$ & .24 \\
\hline Copper, total $(\mu \mathrm{g} / \mathrm{L})$ & 3 & $<20$ & $<20$ & $<20$ & $<20$ & 6 & -- & $<20$ & $<10$ & 7 \\
\hline Iron, dissolved $(\mu \mathrm{g} / \mathrm{L})$ & 3 & 34 & 40 & 22 & 40 & 6 & -- & 27 & $<10$ & 50 \\
\hline Lead, total $(\mu \mathrm{g} / \mathrm{L})$ & 3 & -- & 4 & $<1$ & 9 & 6 & -- & $<2$ & $<1$ & 15 \\
\hline Manganese, dissolved $(\mu \mathrm{g} / \mathrm{L})$ & 3 & 8.8 & 7.0 & 3.4 & 16 & 6 & -- & $<3$ & $<2$ & 6.2 \\
\hline Mercury, total $(\mu \mathrm{g} / \mathrm{L})$ & 3 & -- & $<.14$ & $<.1$ & .02 & 6 & -- & $<.1$ & $<.1$ & .02 \\
\hline Nickel, total $(\mu \mathrm{g} / \mathrm{L})$ & 3 & -- & 2 & $<2$ & 5 & 6 & -- & $<2$ & $<2$ & 8 \\
\hline Zinc, total $(\mu \mathrm{g} / \mathrm{L})$ & 3 & $<31$ & $<31$ & $<31$ & $<31$ & 5 & -- & -- & $<25$ & $<31$ \\
\hline Oil \& grease, total recoverable (mg/L) & 3 & -- & -- & $<1$ & $<7$ & 5 & -- & 1 & $<1$ & 6 \\
\hline Atrazine $(\mu \mathrm{g} / \mathrm{L})$ & 3 & $<.007$ & $<.007$ & $<.007$ & $<.007$ & 5 & $<.007$ & $<.007$ & $<.007$ & .007 \\
\hline Deethylatrazine $(\mu \mathrm{g} / \mathrm{L})$ & 3 & -- & $<.006$ & $<.006$ & .01 & 5 & $<.006$ & $<.006$ & $<.006$ & $<.006$ \\
\hline Trifluralin $(\mu \mathrm{g} / \mathrm{L})$ & 3 & $<.009$ & $<.009$ & $<.009$ & $<.009$ & 5 & $<.009$ & $<.009$ & $<.009$ & $<.009$ \\
\hline
\end{tabular}


Table 6. Densities of bacteria in runoff samples, 2000-2001

[Densities in colonies per 100 milliliters; --, not measured; <, less than]

\begin{tabular}{|c|c|c|c|c|}
\hline Sampling site & $\begin{array}{l}\text { Event } \\
\text { date }\end{array}$ & $\begin{array}{l}\text { Fecal } \\
\text { coliform }\end{array}$ & $\begin{array}{c}\text { Fecal } \\
\text { streptococcus }\end{array}$ & E. coli \\
\hline \multirow[t]{3}{*}{ Moody Creek watershed } & $10 / 06 / 00$ & 6,000 & 12,000 & -- \\
\hline & 01/11/01 & 12,000 & 11,000 & -- \\
\hline & 08/30/01 & 5,300 & 6,000 & 4,380 \\
\hline \multirow[t]{4}{*}{ Watershed 1} & $10 / 06 / 00$ & 76,000 & 7,900 & -- \\
\hline & $10 / 06 / 00$ & 40,000 & 26,000 & -- \\
\hline & 01/11/01 & 11,000 & 12,000 & 3,800 \\
\hline & 08/30/01 & -- & 2,670 & 1,330 \\
\hline \multirow[t]{2}{*}{ Watershed 2} & 08/30/01 & 2,000 & $<1,000$ & $<1,000$ \\
\hline & $11 / 16 / 01$ & 3,080 & -- & -- \\
\hline
\end{tabular}

Table 7. Summary statistics of bacteria densities in combined runoff samples, 2000-2001

[Densities in colonies per 100 milliliters; TSWQS, Texas State Water Quality Standard; <, less than; ,-- not measured]

\begin{tabular}{lcccccc}
\hline \multicolumn{1}{c}{ Bacteria } & $\begin{array}{c}\text { No. of } \\
\text { samples }\end{array}$ & Mean & Median & Minimum & Maximum & TSWQS \\
\hline Fecal coliform & 9 & 17,800 & 6,000 & 2,000 & 76,000 & 1400 \\
Fecal streptococcus & 8 & 9,750 & 9,450 & $<1,000$ & 26,000 & -- \\
E. coli & 5 & -- & 2,560 & $<1,000$ & 4,380 & 2394 \\
\hline
\end{tabular}

\footnotetext{
${ }^{1}$ Indicator bacteria for saltwater is enterococcus. Fecal coliform is an alternative indicator.

${ }^{2}$ Indicator bacteria for freshwater is E. coli. Fecal coliform is an alternative indicator.
} 
Table 8. Monthly and annual loads of selected constituents in runoff, ${ }^{1} 2000-2001$

\begin{tabular}{|c|c|c|c|c|c|c|c|c|c|c|c|c|c|}
\hline \multirow{2}{*}{$\underset{-1}{\stackrel{\Upsilon}{\Sigma}} \quad$ Constituent } & \multicolumn{13}{|c|}{ Runoff load, in pounds } \\
\hline & Jan. & Feb. & Mar. & Apr. & May & June & July & Aug. & Sept. & Oct. & Nov. & Dec. & Annual \\
\hline \multicolumn{14}{|c|}{2000} \\
\hline \multirow{6}{*}{\multicolumn{14}{|c|}{ 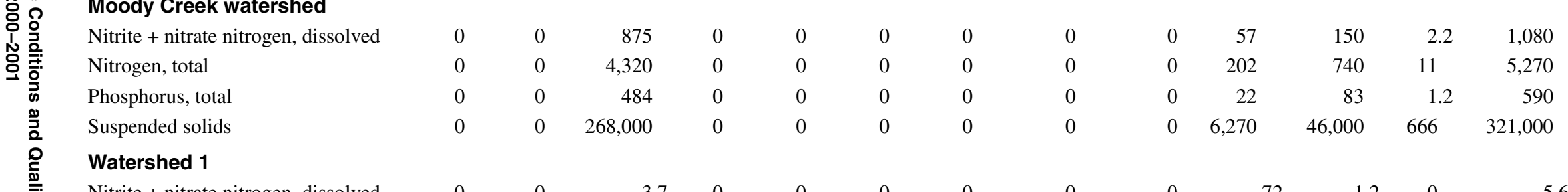 }} \\
\hline & & & & & & & & & & & & & \\
\hline & & & & & & & & & & & & & \\
\hline & & & & & & & & & & & & & \\
\hline & & & & & & & & & & & & & \\
\hline & & & & & & & & & & & & & \\
\hline 昰 $\quad$ Nitrite + nitrate nitrogen, dissolved & 0 & 0 & 3.7 & 0 & 0 & 0 & 0 & 0 & 0 & .72 & 1.2 & 0 & 5.6 \\
\hline \multirow{4}{*}{\multicolumn{14}{|c|}{$\begin{array}{ll}\stackrel{2}{\circ} & \text { Nitrogen, total } \\
\stackrel{D}{D} & \text { Phosphorus, total } \\
\stackrel{\Xi}{\Xi} & \text { Suspended solids } \\
\stackrel{\Xi}{\equiv} & \text { Watershed 2 }\end{array}$}} \\
\hline & & & & & & & & & & & & & \\
\hline & & & & & & & & & & & & & \\
\hline & & & & & & & & & & & & & \\
\hline Nitrite + nitrate nitrogen, dissolved & 0 & 0 & 2.5 & 0 & 0 & 0 & 0 & 0 & 0 & 0 & .26 & 0 & 2.8 \\
\hline Nitrogen, total & 0 & 0 & 20 & 0 & 0 & 0 & 0 & 0 & 0 & 0 & 2.1 & 0 & 22 \\
\hline Phosphorus, total & 0 & 0 & 2.1 & 0 & 0 & 0 & 0 & 0 & 0 & 0 & .21 & 0 & 2.3 \\
\hline Suspended solids & 0 & 0 & 1,180 & 0 & 0 & 0 & 0 & 0 & 0 & 0 & 122 & 0 & 1,300 \\
\hline \multicolumn{14}{|c|}{2001} \\
\hline \multicolumn{14}{|l|}{ Moody Creek watershed } \\
\hline Nitrite + nitrate nitrogen, dissolved & 404 & 0 & 0 & 0 & 0 & 0 & 0 & 399 & 223 & 0 & 394 & 0 & 1,420 \\
\hline Nitrogen, total & 1,660 & 0 & 0 & 0 & 0 & 0 & 0 & 4,170 & 2,330 & 0 & 2,470 & 0 & 10,600 \\
\hline Phosphorus, total & 132 & 0 & 0 & 0 & 0 & 0 & 0 & 687 & 384 & 0 & 284 & 0 & 1,490 \\
\hline Suspended solids & 100,000 & 0 & 0 & 0 & 0 & 0 & 0 & 984,000 & 549,000 & 0 & 157,000 & 0 & $1,790,000$ \\
\hline \multicolumn{14}{|l|}{ Watershed 1} \\
\hline Nitrite + nitrate nitrogen, dissolved & .24 & 0 & 0 & 0 & 0 & 0 & 0 & .81 & 1.9 & 0 & .54 & 0 & 3.5 \\
\hline Nitrogen, total & 7.4 & 0 & 0 & 0 & 0 & 0 & 0 & 5.5 & 13.6 & 0 & 5.1 & 0 & 32 \\
\hline Phosphorus, total & .42 & 0 & 0 & 0 & 0 & 0 & 0 & .51 & 1.2 & 0 & .29 & 0 & 2.4 \\
\hline Suspended solids & 78 & 0 & 0 & 0 & 0 & 0 & 0 & 108 & 264 & 0 & 108 & 0 & 558 \\
\hline \multicolumn{14}{|l|}{ Watershed 2} \\
\hline Nitrite + nitrate nitrogen, dissolved & .33 & 0 & 0 & 0 & 0 & 0 & 0 & .70 & 4.3 & 0 & 2.2 & 0 & 7.5 \\
\hline Nitrogen, total & 2.6 & 0 & 0 & 0 & 0 & 0 & 0 & 11 & 69 & 0 & 9.3 & 0 & 92 \\
\hline Phosphorus, total & .28 & 0 & 0 & 0 & 0 & 0 & 0 & 1.3 & 8.5 & 0 & 1.2 & 0 & 11 \\
\hline Suspended solids & 163 & 0 & 0 & 0 & 0 & 0 & 0 & 2,600 & 17,200 & 0 & 835 & 0 & 20,800 \\
\hline
\end{tabular}

\footnotetext{
${ }^{1}$ Sums of monthly loads might not equal annual loads because of rounding.
} 
Rangeland Areas in San Patricio County, Texas, 2000-2001

District Chief

U.S. Geological Survey

8027 Exchange Dr.

Austin, TX 78754-4733 